\title{
ANTICORPOS CATALÍTICOS: EXPANDINDO O ALCANCE DA CATÁLISE ENZIMÁTICA
}

\author{
Giselle Zenker Justo \\ Instituto de Química - Universidade Estadual de Campinas - CP 6154 - 13081-970 - Campinas - SP
}

Recebido em 25/11/96; aceito em 2/4/97

\begin{abstract}
CATALYTIC ANTIBODIES: EXPANDING THE SCOPE OF ENZYMATIC CATALYSIS. The vast binding repertoire of the immune system has been exploited for the generation of tailor-made selective catalysts. Since the first reports of chemical reactions catalyzed by antibodies were published, research in this field, which borders chemistry and biology, has been rapidly established and a number of catalytic antibodies that carry out a wide range of reactions, have been developed. Recent advances have led to antibodies that catalyse complex, multi-step reactions and difficult chemical transformations, as well as reactions that do not have an organic equivalent at all. Current research in this field has been devoted to practical applications of this technology.
\end{abstract}

Keywords: catalytic antibodies; abzymes; antibody catalysis.

\section{INTRODUÇÃO}

Embora espetaculares avanços tenham sido alcançados na compreensão dos mecanismos de reações químicas e na síntese de moléculas complexas, a química não poderia se igualar à habilidade da natureza em gerar estruturas moleculares complexas envolvidas nos marcantes processos da vida como, por exemplo, reconhecimento molecular, catálise enzimática e regulação gênica.

A catálise de reações químicas é uma das áreas mais exploradas. Entretanto, a habilidade ilimitada de selecionar ou programar catalisadores específicos para qualquer transformação química desejada, a partir de qualquer reagente químico, ainda não foi alcançada. $\mathrm{O}$ desenho racional de catalisadores específicos ainda é um problema difícil para ambos, químicos sintéticos e bioquímicos. Uma solução bem sucedida para este problema, utiliza a diversidade do sistema imune para produzir uma nova classe de enzimas: os anticorpos catalíticos. Sua habilidade em selecionar um dentre $10^{12}$ possíveis anticorpos que se ligam virtualmente a qualquer molécula de interesse, faz do sistema imune uma fonte atrativa de catalisadores específicos.

Os primeiros avanços resultaram da contribuição pioneira de químicos e imunologistas ao desenho molecular e à produção de hibridomas. Em menos de cinco anos, esta união revolucionária propiciou a evolução da concepção da idéia de anticorpos catalíticos para a prática demonstrada, havendo, ainda, todo um potencial para ser explorado acerca desta nova classe de catalisadores.

Os anticorpos são proteínas, pertencentes à classe das globulinas, geradas pelo sistema imune para reconhecer substâncias estranhas, denominadas de antígenos, e iniciar o processo de neutralização ou destruição destes agentes. $\mathrm{O}$ reconhecimento seletivo ocorre através de interações fracas, sendo capazes de discriminar, com alta afinidade e seletividade específica $\left(\mathrm{K}_{\mathrm{a}} \mathrm{s}\right.$ da ordem de $10^{14} \mathrm{M}^{-1}$ ), um espectro amplo de moléculas, naturais ou sintéticas. Os anticorpos são proteínas homodiméricas com um peso molecular de $150.000 \mathrm{Da}$, com duas regiões combinantes ligantes idênticas, fragmentos Fab. Os sítios combinantes são definidos pelas regiões hipervariáveis das cadeias polipeptídicas leve e pesada $\left(\mathrm{V}_{\mathrm{L}}\right.$ e $\mathrm{V}_{\mathrm{H}}$ respectivamente), e compreendem os primeiros 110 resíduos amino-terminais destes polipeptídios. Mais de $10^{8}$ diferentes moléculas de anticorpos tornam-se disponíveis através de processos de recombinação gênica de $V_{L}$ e $V_{H}$. Um complexo sistema de seleção, acoplado a eventos celulares subsequentes, tais como mutações somáticas e afinidade de maturação, proporcionam um aumento de milhões de vezes de variantes estruturais, fornecendo uma fonte atrativa de moléculas com especificidade molecular incomparável e em uma escala de tempo de semanas ${ }^{1,2}$.

O estabelecimento conceitual de anticorpos catalíticos advém da conjetura de Linus Pauling quanto à obtenção de anticorpos catalíticos ${ }^{3}$. Basicamente, a diferença entre anticorpos e enzimas não é fundamental, mas meramente de especificidade. Enzimas catalisam reações por estabilizarem preferencialmente estados de transição, proporcionando diminuição da energia livre de ativação ao longo da coordenada de reação. Anticorpos são extremamente eficientes quanto à capacidade de ligação, podendo exceder a de enzimas, mas o fazem ao estado fundamental ${ }^{3}$. Jencks ${ }^{4}$, há mais de vinte anos, elaborou este conceito e sugeriu que, se anticorpos pudessem ser persuadidos a ligarem-se ao estado de transição eles, então, deveriam, em teoria, adquirir propriedades catalíticas; designando o termo "abzyme" para descrever estes híbridos anticorpo-enzima. Entretanto, apenas em 1975, as primeiras tentativas experimentais para a obtenção de anticorpos catalíticos foram descritas por Raso e Stollar ${ }^{5,6}$. Nestes experimentos, coelhos foram imunizados com uma base de Schiff estável, intermediária de uma reação de transaminação tirosinapiridoxal, sem que nenhuma atividade catalítica fosse detectada dentre as frações do soro policlonal ${ }^{5,6}$. Tal insucesso foi atribuído, em grande parte, às dificuldades associadas ao isolamento e purificação de suas preparações de anticorpos policlonais.

Em 1975, Kohler e Milstein ${ }^{7}$ propuseram uma elegante solução para este problema com o desenvolvimento pioneiro de híbridos de células imunes imortalizadas, especializadas na produção de anticorpos monoclonais. Esta técnica ${ }^{8,9}$ tornou possível a obtenção reprodutível de quantidades significativas de amostras de anticorpos homogêneos, as quais são cruciais para a caracterização do processo catalítico. Desde a sua descoberta, a tecnologia do hibridoma expandiu dramaticamente a importância dos anticorpos na química, biologia e medicina. Entretanto, mais de uma década se passou até que o potencial químico do sistema imune fosse demonstrado por Schultz e Lerner em 1986, através da geração de anticorpos catalíticos, induzidos por análogos de estados de transição fosfato e fosfonato, tetraédricos e negativamente carregados, para a hidrólise de carbonatos e ésteres respectivamente ${ }^{10,11}$. Desde estes estudos iniciais, transformações catalisadas por anticorpos incluem reações de clivagem de amidas, carbonatos e ésteres, bem como as reações reversas correspondentes; hidrólise de ligações peptídicas; rearranjos 
de Claisen; cicloadições tipo foto-induzidas e fotocicloreversões; processos redox; eliminações E2; isomerizações cis-trans; reações utilizando-se metais quelantes; lactonizações; e reações de Diels-Alder, exibindo alta enancioseletividade.

A arte de gerar estes catalisadores reside no desenho do hapteno, que deve ser quimicamente estável ao mesmo tempo que deve mimetizar as propriedades eletrônicas e estruturais do estado de transição da reação em questão. Para produzir tais anticorpos o sistema imune é desafiado com o hapteno apropriado, conjugado a uma proteína carreadora. Os anticorpos resultantes ligam-se preferencialmente ao estado de transição da reação alvo e, como consequência, observa-se um aumento na velocidade da reação. Tais anticorpos desafiam enzimas naturais em termos de eficiência catalítica e seletividade pelo substrato ${ }^{12}$.

Nos últimos 10 anos, a pesquisa nesta área teve por objetivo definir o alcance da catálise por anticorpos e determinar quais classes de reações químicas são acessíveis ao processo catalítico, através do desenho do análogo do estado de transição da reação. Atualmente, considerável atenção vem sendo dispensada ao desenho racional de anticorpos envolvidos em mecanismos de reações complexas, ocorrendo em multi-etapas, bem como anticorpos que catalisam seletivamente transformações químicas difíceis ou que, em geral, não ocorrem na química biológica. O alcance da catálise por anticorpos é bastante amplo e é razoável assumir que qualquer reação química, para a qual um análogo do estado de transição possa ser sintetizado, irá apresentar um anticorpo com alguma atividade catalítica. Uma série das reações químicas para as quais anticorpos catalíticos são gerados foi revista em $1991^{13}$. Além disso, inúmeros outros artigos de revisão, abordando diferentes aspectos na área, estão disponíveis na literatura ${ }^{14-19}$.

\section{GERAÇÃO DE ANTICORPOS CATALÍTICOS}

A catálise por anticorpos intera dois elementos principais reconhecimento e capacidade catalítica. $\mathrm{O}$ reconhecimento permite ao anticorpo selecionar uma ou uma pequena série de moléculas funcionalmente capazes de participar na reação química catalisada, sendo este reconhecimento seletivo um atributo único dos anticorpos catalíticos. A capacidade catalítica é a soma de fatores que resulta em uma diminuição da energia livre de ativação para a etapa determinante da velocidade da reação. Como sugerido por Pauling $^{3}$, um destes fatores corresponde às interações favoráveis de ligação entre anticorpo e reagente para estabilizar uma conformação de alta energia. Um segundo componente visa minimizar a entropia desfavorável associada à uma pré-organização ou orientação dos reagentes. Um terceiro aspecto da catálise é o alojamento preciso de grupos funcionais catalíticos essenciais ou de cofatores para executar a transformação química ${ }^{3}$.

Muitas ferramentas estão disponíveis para a obtenção de anticorpos catalíticos, sendo que o hapteno utilizado para inferir a especificidade imune desejada, é a mais importante ${ }^{12,13,20}$. O desenho do hapteno é crítico, uma vez que sua estrutura e funcionalidade irão definir ou ditar a topologia do(s) sítio(s) combinante(s) do anticorpo selecionado do reservatório imunológico. Então, a configuração efetiva do hapteno deve aproximar-se da geometria do estado de transição, com incorporação de funcionalidade específica, que irá resultar em um alojamento propício dos resíduos de aminoácidos catalíticos necessários no sítio combinante. A segunda ferramenta importante empregada é a introdução direta de grupos funcionais catalíticos nos sítios combinantes dos anticorpos, através de modificação química direta. Uma vez que uma determinada capacidade catalítica tenha sido obtida, a modificação química dirigida, utilizando-se diferentes ligantes, pode ser utilizada para incorporar grupos catalíticos adicionais ou cofatores. A terceira ferramenta corresponde à mutação sítio-dirigida. Esta técnica, extensivamente utilizada para produzir modificações em sítios ativos de enzimas, vem sendo aplicada também para aumentar a capacidade catalítica dos sítios combinantes de anticorpos ${ }^{12,13,20}$. A capacidade de gerar sítios combinantes nos anticorpos com grupos catalíticos e/ou microambientes específicos proporciona, em conjunto aos catalisadores seletivos disponíveis, um estudo da contribuição dos vários fatores envolvidos em catálise enzimática, incluindo estabilização do estado de transição, catálise ácido-base geral, torção do estado fundamental, bem como efeitos de proximidade.

Muitos dos anticorpos catalíticos descritos até o presente foram gerados pela técnica clássica do hibridoma, a qual envolve, tipicamente, quatro etapas: (1) imunização do camundongo com o conjugado hapteno-proteína carreadora; (2) geração de clones híbridos, imortalizados através da fusão de células esplênicas e células de mieloma provenientes de roedores; (3) seleção de clones individuais para ligação específica do anticorpo ao hapteno; e (4) seleção dos anticorpos exibindo a atividade catalítica desejada. Entretanto, é essencial que os anticorpos catalíticos sejam completamente purificados de possíveis contaminações com enzimas endógenas, que poderiam ser capazes de catalisar o mesmo tipo de reação em estudo ${ }^{7,21}$.

Diferentes metodologias têm sido descritas para a seleção direta de sobrenadantes híbridos com função catalítica. A primeira, designada por catELISA, baseia-se no uso de um substrato imobilizado, e na detecção do produto imobilizado com o anticorpo específico para formar o produto. A escolha do substrato a ser imobilizado e o sítio de ligação são escolhidos com a finalidade de se maximizar as diferenças antigênicas entre o substrato e o produto, evitando-se interferências na reação e mantendo-se a acessibilidade sintética. Por exemplo, o substrato derivado de maleimida (Figura 1, estrutura 2), foi imobilizado através de ligação covalente com BSA (soroalbumina bovina), que adere fortemente às superfícies de poliestireno das microplacas ${ }^{22}$. A reação com o dieno dióxido de tetraclorotiofeno (1) foi estudada na ausência e na presença do anticorpo catalítico $1 \mathrm{E} 9^{22}$. Uma variação deste procedimento básico mostrou ser eficiente na obtenção de anticorpos que catalisam uma reação bimolecular de DielsAlder $^{23}$. Neste caso, o dienófilo foi imobilizado em um suporte sólido e o dieno mantido livre em solução. Uma outra maneira é testar o anticorpo secretado em um estágio inicial no procedimento de seleção, através da ligação a substâncias que também representam estruturas do estado de transição, mas diferentes do hapteno utilizado para a imunização ${ }^{24}$. Tawfik et. al. ${ }^{24}$ otimizaram a seleção racional de anticorpos monoclonais capazes de catalisar a hidrólise de ésteres e carbonatos, através de experimentos de inibição competitiva, baseando-se na afinidade dos clones produtores de anticorpos catalíticos por um análogo "pequeno" do estado de transição, um hapteno truncado que maximiza a contribuição relativa

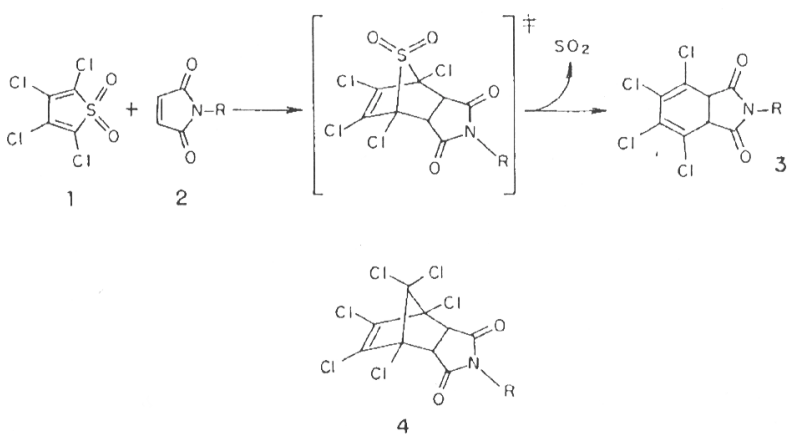

Figura 1. Reação de Diels-Alder do dióxido de tetraclorotiofeno (1) com o derivado de $\mathrm{N}$-maleimida (2). A estrutura 4 corresponde ao hapteno (análogo do estado de transição) utilizado para a produção de anticorpos catalíticos 

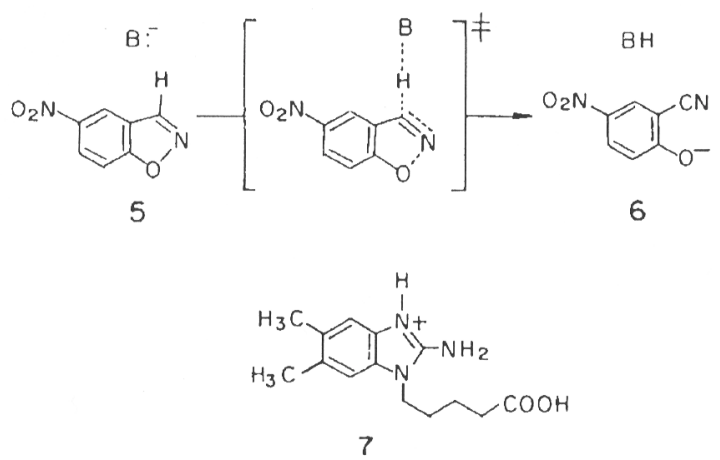

Figura 2. Eliminação E2 concertada catalisada por uma base, iniciada pela abstração de um próton de um carbono ácido. A estrutura 7 corresponde ao hapteno utilizado na preparação de anticorpos catalíticos.

dos elementos estruturais do estado de transição à ligação e minimiza os elementos comuns ao substrato, estado de transição e produto. Espera-se que os anticorpos monoclonais selecionados desta maneira se liguem ao estado de transição mais fortemente do que ao(s) reagente(s) e produto(s), exibindo alta frequência de transformação ("turnover") e alta eficiência catalítica ${ }^{24}$. Portanto, os clones com potencial catalítico devem ser mais facil e rapidamente selecionados, exibindo características essenciais de reações enzimaticamente catalisadas, as quais raramente são atingidas por modelos químicos ou bioquímicos.

Reações que liberam um grupo cromogênico ou fluorogênico são, em princípio, utilizadas como estratégia para a identificação de anticorpos catalíticos com atividade específica. Um exemplo de utilização desta estratégia é a identificação de anticorpos catalíticos específicos para uma reação de eliminação E2, cujo produto absorve fortemente em $340 \mathrm{~nm}$ (Figura 2, estrutura 6$)^{25}$. Esta propriedade foi utilizada para selecionar hibridomas de células B imunizadas com o hapteno 7, capaz de induzir um resíduo no sítio ativo catalítico que atuasse como uma base geral. Dois catalisadores altamente ativos foram identificados, apresentando um valor de $\mathrm{k}_{\text {cat }}$ de aproximadamente $30 \mathrm{~min}^{-1}$ e uma aceleração da velocidade da reação da ordem de $10^{8}$. Além disso, um $\mathrm{pK}_{\mathrm{a}}$ aparente de aproximadamente 6 foi atribuído a um resíduo Glu ou Asp induzido no sítio ativo do anticorpo ${ }^{25}$. Pollack et. al. $^{26}$ utilizaram substratos fluorogênicos, que permitiram uma medida direta da cinética de hidrólise estereoespecífica da D-fenilalanina, através da supressão do fluoróforo antranilamida por um grupo nitro-aromático via transferência de energia de ressonância. Esta técnica de transferência de energia é um método alternativo, utilizado na avaliação de um amplo espectro de reações de clivagem, facilitando a seleção de anticorpos específicos ${ }^{27,28}$.

Para algumas aplicações é possível contornar a produção de hibridomas através da clonagem e expressão do repertório de imunoglobulinas em bibliotecas de bacteriófagos $\lambda^{29-31}$. A metodologia do DNA recombinante vem se tornando cada vez mais efetiva para a geração rápida e eficiente de fragmentos Fab catalíticos $^{32,33}$. Estratégias utilizando-se PCR (reação em cadeia com polimerase) têm sido desenvolvidas, tornando possível a amplificação seletiva de cDNAs codificadores de $\mathrm{V}_{\mathrm{L}}$ e $\mathrm{V}_{\mathrm{H}}{ }^{29,34}$. Entretanto, dois inconvenientes destas técnicas para a identificação de anticorpos catalíticos são: as dificuldades associadas à expressão funcional dos fragmentos do anticorpo na bactéria, e $o$ fato de que no processo de clonagem, os genes de $V_{L}$ e $V_{H}$ são recombinados ao acaso, havendo uma probabilidade muito baixa de pareamento exatamente como ocorre nas células B.

A expressão em fago filamentoso e seleção in vitro para identificação de anticorpos catalíticos sítio-ativos seletivos compreende uma variação deste tema ${ }^{35}$. A expressão de bibliotecas de anticorpos em fago filamentoso foi um dos principais avanços, pois o tamanho e composição das bibliotecas não estão mais limitados ao sistema natural de seleção. A utilidade dos sistemas de expressão em fago é que a essência do sistema natural de anticorpos pode ser duplicada no fago através da ligação reconhecimento-replicação. A seleção in vitro de uma biblioteca de anticorpos expressa em fago filamentoso contra um composto dissulfeto, constitui um exemplo bem sucedido para a identificação de anticorpos catalíticos contendo um sítio ativo Cys capaz de atuar como nucleófilo na hidrólise de tioésteres. O anticorpo contendo o resíduo Cys, provavelmente, foi selecionado devido a formação de uma ligação dissulfeto covalente com o composto imobilizado através de uma reação de troca de dissulfeto ${ }^{36}$. Tal estratégia pode, em princípio, ser generalizada a outros tipos de reações sujeitas à catálise nucleofílica.

\section{ANTICORPOS CATALÍTICOS E O ANÁLOGO DO ESTADO DE TRANSIÇÃO}

O desafio imposto pela catálise por anticorpos é justamente quanto à reatividade química ou como se poderia explorar a afinidade e especificidade da molécula de anticorpo (ligações não covalentes fracas) para formar ligações químicas covalentes. A primeira proposta sugere estabilização seletiva do estado de transição determinante da velocidade da reação, refletindo o fato de muitas enzimas possuírem um sítio ativo estericamente e eletronicamente complementar ao estado de transição limitante da velocidade da reação ${ }^{13}$.

A primeira demonstração experimental desta noção envolveu reações de transferência de grupo acila, especificamente reações simples de hidrólise ${ }^{10,11,13,15,37}$. A proposta parece lógica do ponto de vista de que estas reações são objeto de interesse para os físico-químicos orgânicos, estando dentre as reações mais amplamente estudadas. Além disso, a natureza estérica e eletrônica do estado de transição destas reações (tetraédrico e negativamente carregado) é suficientemente diferente do substrato (planar e neutro).

Desde os primeiros experimentos muitas reações envolvendo a transferência de grupo acila foram catalisadas. Um destes importantes experimentos discute as aplicações comerciais dos anticorpos, incluindo a demonstração de catálise de reação de hidrólise de éteres inativados estereoespecificamente, com um excesso enanciomérico maior do que $99 \%{ }^{38}$. Estes resultados são significativos já que até o momento não existe um método químico geral para a produção de catalisadores estereolíticos estereoespecíficos. Especificidade para funções álcool ou ácido presentes em ésteres foi demonstrada, bem como para as configurações $R$ e $S^{13,26,39}$. Tais anticorpos poderiam ser aplicados na resolução quiral de intermediários sintéticos contendo funções álcool ou ácido. De fato, a especificidade de anticorpos estereolíticos já foi explorada na produção de um biosensor ${ }^{13}$.

Os primeiros anticorpos catalíticos específicos para hidrólise de ésteres e carbonatos, ligaram-se a análogos de estados de transição fosfato e fosfonatos tetraédricos negativamente carregados (Figura 3; estruturas 10, 13 e 14), além dos grupos $\alpha$, $\alpha$-difluorocarbonila e hidroximetileno ${ }^{10,11,13,15,26,37}$. As reações de hidrólise não requerem, necessariamente, cadeias laterais catalisadoras ativas (por exemplo, um nucleófilo Ser); elas também podem ocorrer pelo simples ataque de uma molécula de água na carbonila polarizada do substrato no sítio de ligação.

Anticorpos específicos para os análogos do estado de transição $\mathbf{1 0}, 13$ e 14 seletivamente catalisaram a hidrólise dos substratos correspondentes 8, 11 e 12 (Figura 3), consistente com a cinética Michaeliana $a^{10,11,37,40}$. Tais reações foram competitivamente inibidas pelo análogo do estado de transição correspondente. As constantes de inibição $\left(\mathrm{K}_{\mathrm{i}}\right)$ foram substancialmente menores do que as constantes de Michaelis-Menten $\left(\mathrm{K}_{\mathrm{m}}\right)$ para os substratos, sugerindo que a estabilização do estado de 


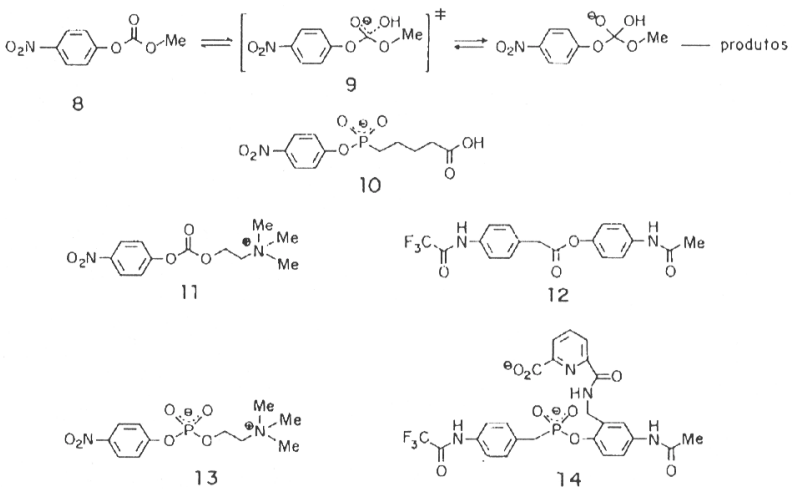

Figura 3. Reação de hidrólise de éteres. As estruturas 10, 13 e 14 correspondem aos análogos dos estados de transição das reações de hidrólise dos substratos 8,11 e 12, respectivamente.

transição é fundamental na catálise. Uma aceleração na velocidade da reação catalisada em relação à não catalisada da ordem de $10^{3}-10^{5}$ foi observada. Estes resultados concordam com a variação encontrada para enzimas hidrolíticas ${ }^{10,37,40}$. Por exemplo, um mutante da enzima subtilisina hidrolizou o peptídeo p-nitroanilida 3000 vezes mais rapidamente do que a reação não catalisada ${ }^{41}$. Em todos os casos os anticorpos exibiram alta especificidade pelos substratos.

A elucidação da estrutura tridimensional do anticorpo McPC603, o qual é altamente homólogo aos anticorpos catalíticos T15 e MOPC167 ligantes de fosforilcolina, possibilitou a identificação dos resíduos sítio-combinantes responsáveis pela catálise ${ }^{42}$. O hapteno é ligado ao anticorpo com o grupo colina no interior da cavidade sítio-combinante e o grupo fosfato voltado para o exterior, em contato com o solvente aquoso. Os resíduos Tyr-H33 e Arg-H52 da cadeia pesada ligam-se ao grupo fosfato por ligações hidrogênio e interações eletrostáticas com os átomos de oxigênio fosforílicos. $\mathrm{O}$ anticorpo é então capaz de polarizar o grupo carbonila de $\mathbf{1 1}$ para o ataque do íon hidróxido na etapa determinante da velocidade. Uma vez que a estrutura do estado fundamental de $\mathbf{1 1}$ difere substancialmente da configuração do estado de transição (9), a afinidade de ligação diferenciada do anticorpo por estas duas espécies resulta em uma diminuição na energia livre de ativação da reação. De fato, o análogo do estado de transição 13, liga-se mais fortemente aos anticorpos MOPC167 e T15 $\left(\mathrm{K}_{\mathrm{i}}=5 \mu \mathrm{M} ; \mathrm{K}_{\mathrm{m}}=208 \mu \mathrm{M}\right)$. Ademais, dados de cristalografia, em conjunto com estudos biofísicos, sugerem que anticorpos específicos para o hapteno 10 reduzam a barreira de energia da reação através da ação catalítica da Tyr e Arg, enquanto que His ou Tyr estariam envolvidas na estabilização do estado de transição tetraédrico para reações catalisadas por anticorpos específicos para $\mathbf{1 4}$ (Figura 3) $\mathbf{1 0 , 1 1 , 1 5 , 2 6 , 3 7 , 4 0 .}$.

Experimentos relacionados, que poderiam ser expandidos para aplicações comerciais, foram as demonstrações de que (1) anticorpos podem agir como catalisadores em solventes orgânicos, pela solubilização em micelas reversas ${ }^{43}$ e, (2) anticorpos imobilizados mantêm atividade e especificidade (com estabilidade aumentada) em solventes orgânicos ${ }^{44}$. Recentemente, um anticorpo catalítico recoberto com uma camada lipídica foi preparado misturando-se soluções aquosas do anticorpo com glicolipídios sintéticos, tornando-o solúvel em solventes orgânicos ${ }^{45}$. Uma marcada reatividade foi demonstrada para a hidrólise de alquil-ésteres lipofílicos em solução tampão Tris 0,05M, pH 8,0; contendo 20-80\% de $\mathrm{DMSO}^{45}$.

Anticorpos catalíticos capazes de clivar ligações peptídicas seriam de grande utilidade em terapêutica e também como ferramenta de pesquisa. Por exemplo, o acesso a uma família de proteases poderia facilitar estudos de estrutura-função de novas proteínas, e anticorpos proteolíticos específicos para as proteínas do envelope viral poderiam ser úteis na terapia antiviral. Entretanto, a estabilidade inerente às amidas $\left(\mathrm{t}_{1 / 2}\right.$ ^ 7 anos) sugere que a hidrólise por anticorpos seja de difícil execução, uma vez que a barreira de energia para a formação e quebra do intermediário tetraédrico são muito maiores para amidas do que para ésteres. Dois exemplos de anticorpos catalíticos com modesta atividade de amidase catalisaram a hidrólise de uma nitrofenilanilida $^{46}$ e de peptídeos ${ }^{47}$. Recentemente, Martin et. al. ${ }^{48}$ demonstraram a obtenção de um anticorpo seletivo para a hidrólise do enanciômero $\mathrm{R}$ de uma fenilalanina inativada, a partir de um análogo do estado de transição fosfinato racêmico. Entretanto, como nos exemplos anteriores, apenas uma modesta atividade catalítica foi atingida $\left(\mathrm{k}_{\mathrm{cat}}=1 \times 10^{-5} \mathrm{~min}^{-1} ; \mathrm{k}_{\mathrm{cat}} / \mathrm{k}_{\mathrm{uncat}}=132\right)$, demonstrando a dificuldade intrínsica no desenvolvimento de catalisadores para a hidrólise de amidas ${ }^{48}$.

Grande ênfase vem sendo dada à compreensão das características mecanísticas e estruturais da catálise por anticorpos. $\mathrm{O}$ objetivo fundamental visa a obtenção futura de análogos do estado de transição que forneçam anticorpos mais efetivos, além de melhorar a atividade da primeira geração de anticorpos catalíticos, através de mutagênese sítio-dirigida ${ }^{49,50}$. O anticorpo 43C9, com atividades amidase e esterase, é um dos anticorpos mecanisticamente mais estudados. Os dados acumulados de diferentes estudos mecanísticos sugerem que, reações de hidrólise de ésteres e amidas catalisadas pelo anticorpo 43C9 ocorram via um sofisticado mecanismo envolvendo catálise nucleofílica $^{18}$. Uma estrutura tridimensional, baseada em modelagem computacional, foi proposta por Roberts et. al. $^{51}$.

$\mathrm{O}$ anticorpo 17E8 (Figura 4) é uma esterase que catalisa a hidrólise de ésteres fenílicos de $\mathrm{N}$-acil-aminoácidos ${ }^{52}$. O anticorpo foi gerado contra o análogo norleucina-fenil fosfonato, sendo o $\mathrm{N}$-formil norleucina fenil éster um dos melhores substratos para a enzima. A estrutura cristalina do fragmento Fab complexado ao análogo fosfonato foi obtida e mostrou ter características semelhantes às hidrolases naturais ${ }^{53}$. O sistema se caracteriza por ser um modelo simples de enzimas proteolíticas, contendo um subsítio $\mathrm{S}$ isolado para o reconhecimento da cadeia hidrofóbica lateral do resíduo do aminoácido do substrato. Em estudos cinéticos iniciais foi observado que a reação de hidrólise ocorre enancioseletivamente ${ }^{52}$. Informações adicionais acerca da enancioseletividade da reação de hidrólise foi obtida a partir da estrutura cristalina do anticorpo 17E8, mostrando que apenas o enanciômero $S$, com a mesma configuração do carbono- $\alpha$ do substrato, se liga ao sítio ativo, embora o substrato racêmico tenha sido utilizado no experimento ${ }^{53}$. Recentemente, Wade e Scanlan ${ }^{54}$ confimaram a enancioseletividade $\mathrm{S}$ do anticorpo $17 \mathrm{E} 8$ para a hidrólise, e mostraram que tanto a enancioseletividade como a atividade catalítica são controladas por interações hidrofóbicas entre a cadeia hidrofóbica lateral do substrato e a cavidade $\mathrm{S}$ da enzima.

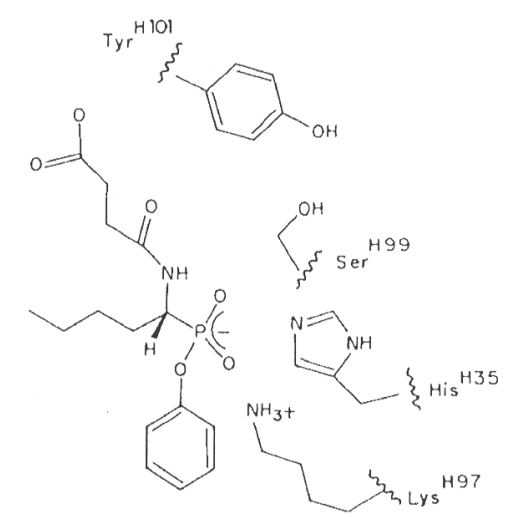

Figura 4. Sitio ativo do anticorpo estereolítico 17E8 complexado ao isômero L do hapteno utilizado para mimetizar a estrutura do estado de transição da reação de estereólise enancioseletiva. 
O anticorpo CNJ206, uma nitrofenilesterase, catalisa a hidrólise do nitrofenil éster com um significativo aumento na velocidade $\left(\mathrm{k}_{\text {cat }} / \mathrm{k}_{\text {uncat }}=1600\right)$, exibindo especificidade pelo substrato ${ }^{24}$. Múltiplos ciclos foram verificados quando o anticorpo foi selecionado utilizando-se sua alta afinidade pelo análogo "pequeno" do estado de transição. Recentemente, Charbonnier et. al. $^{55}$ determinaram a estrutura de raio-X do complexo fragmento Fab-análogo do estado de transição fosfonato. Uma comparação com a estrutura do fragmento não complexado sugere mudanças conformacionais induzidas pelo hapteno. Foi também demonstrado que três ligações hidrogênio são responsáveis pela estabilização do grupo fosfonato do hapteno. O sítio combinante mostrou elevada similaridade com o do anticorpo 17E8, sendo que a estrutura de ambos sugere que a estabilização do oxiânion tem um papel fundamental na aceleração da velocidade da reação ${ }^{55}$.

Além destes exemplos, a complementaridade ao hapteno tem sido aplicada na catálise de reações de eliminação ${ }^{56,57}$, desidratação $^{58}$, hidrólise de enol-éteres ${ }^{59-61}$, isomerização cis-trans $^{62}$, e ciclização catiônica ${ }^{63-65}$. Em particular, nos exemplos de reações de ciclização catiônica, os haptenos utilizados permitiram a geração de anticorpos capazes de acomodar reações envolvendo múltiplos intermediários.

\section{ANTICORPOS CATALÍTICOS E ENTROPIA}

Há muita discussão sobre a relação existente entre efeitos de proximidade e aceleração de velocidade em catálise biológica. Efeitos entrópicos podem produzir molaridades efetivas da ordem de $10^{8} \mathrm{M}$ em reações enzimáticas ${ }^{13}$. Sendo assim, anticorpos deveriam catalisar reações com entropias de ativação desfavoráveis, agindo como sequestradores de entropia, ou seja, a energia de ligação do anticorpo seria usada para congelar os graus de liberdade rotacional e translacional necessários à formação do complexo ativado ${ }^{13}$. Estas noções foram empregadas no projeto de anticorpos que catalisaram reações unimoleculares (lactonização ${ }^{66}$ e rearranjos de Claisen ${ }^{67}$ ), bem como reações bimoleculares (reações de Diels-Alder ${ }^{68,69}$ e transacilações ${ }^{66,70,71}$ ).

Um dos resultados mais interessantes foi a descoberta de um anticorpo eficiente para a catálise da reação de transesterificação em água entre álcool sec-feniletílico e um éster enólico formando o éster quiral correspondente ${ }^{70}$. A reação foi altamente eficiente, com molaridade efetiva da ordem de $10^{6}-10^{8} \mathrm{M}$, sendo a aceleração de natureza entrópica. A cinética mostrou um comportamento do tipo "ping-pong", onde a primeira etapa consiste da formação de um complexo covalente enzimático ${ }^{72}$.

A velocidade de muitas reações, incluindo substituições nucleofílicas $\mathrm{S}_{\mathrm{N}} 2$ e eliminações E2, são altamente sensíveis à escolha do solvente, embora, no caso de reações enzimáticas, a contribuição do efeito de solvatação na aceleração da velocidade seja difícil de ser estimada. O efeito do meio reacional foi estudado na velocidade de descarboxilação de 3-carboxibenzisoxazol em cianofenol. Foi sugerido que o hapteno (Figura 2, estrutura 7), positivamente carregado, seria capaz de gerar anticorpos que apresentassem um grupo carboxilato complementar, negativamente carregado. Este grupo seria, então, precisamente posicionado para atuar como uma base geral ${ }^{16}$. Em um trabalho mais recente, a dependência do $\mathrm{pH}$ da reação de eliminação E2 de benzisoxazol, bem como estudos envolvendo modificação química indicam a presença de um resíduo carboxilato capaz de abstrair um átomo de hidrogênio com alta eficiência, devido a natureza hidrofóbica da cavidade de ligação ${ }^{25}$. A comparação entre a constante de velocidade de segunda ordem, $\mathrm{k}_{\mathrm{AcO}}{ }^{-}$(eliminação catalisada do acetato), e o valor de $\mathrm{k}_{\mathrm{cat}} / \mathrm{K}_{\mathrm{m}}$ concorda com um aumento na velocidade $>10^{8}$ vezes $^{25}$. Cálculos de mecânica quântica aplicados ao sistema modelo de reação de isoxazol com formiato, confirmaram que a orientação do grupo carboxilato tem um efeito significativo na velocidade ${ }^{73}$. Foi determinado que ligação hidrogênio com o óxido formado poderia levar a um aumento ainda maior na aceleração. Além disso, foi sugerido ser a água o ácido geral mais efetivo, seguida de metanol e ácido fórmico. Tais efeitos combinados, orientação própria da base e catálise ácida, levariam a um aumento adicional de $10^{5}-10^{6}$ vezes na velocidade da reação. Baseado nestes resultados, vários haptenos foram propostos e avaliados ${ }^{73}$.

A transformação do corismato 15 em prefenato 17 (Figura 5) é uma etapa chave na biossíntese dos aminoácidos aromáticos Phe e Tyr em bactérias, fungos e vegetais superiores. Esta reação é o único rearranjo [3,3]-sigmatrópico conhecido catalisado por uma enzima, a corismato mutase. A reação é formalmente um rearranjo de Claisen, ocorrendo através de um estado de transição assimétrico na conformação cadeira $(\mathbf{1 6})^{74}$. A posição central desta enzima em organismos inferiores e sua ausência em mamíferos a torna um alvo atrativo para o desenvolvimento de inibidores, bactericidas, fungicidas e herbicidas. A biologia e o mecanismo único têm levado ao estudo extensivo do rearranjo corismato-prefenato nas últimas duas décadas. Estudos mecanísticos e evidências cristalográficas sobre a estrutura, levaram à conclusão de que a enzima catalisa a reação através de um mecanismo concertado. Da mesma forma, a reação pode ser acelerada por anticorpos catalíticos utilizandose um análogo estável do estado de transição ${ }^{15,17,67,68,75,76}$.

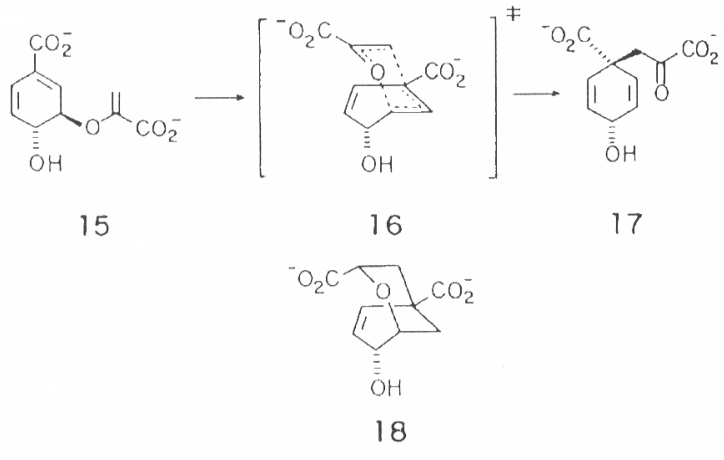

Figura 5. Rearranjo de Claisen do corismato (15) em prefenato (17). Anticorpos monoclonais catalíticos para a reação foram obtidos utilizando-se o hapteno 18.

O análogo do estado de transição 18 (Figura 5) foi utilizado para gerar dois anticorpos com atividade corismato mutase ${ }^{75,76}$. Um dos anticorpos, 1F7, acelerou o rearranjo 190 vezes, devido a diminuição da entalpia de ativação, já que a entropia de ativação é mais desfavorável do que para a reação não catalisada. O segundo anticorpo, 11F1-2E11, catalisou a reação por um fator de $10^{4}$, principalmente devido ao aumento na entropia de ativação. Neste caso, apenas foi observada uma pequena diminuição da entalpia de ativação ${ }^{77}$.

A estrutura tridimensional do anticorpo 1F7 complexado ao hapteno foi determinada recentemente ${ }^{78}$. Apenas algumas interações consideráveis foram observadas entre o hapteno e o sítio de ligação, em relação ao sítio ativo da enzima. Foram demonstradas interações entre o carboxilato na posição C-10 e Arg-H59 e Asp-H97. O carboxilato na posição C-11 interage com Tyr-L94 e Asn-H50, enquanto o grupo hidroxila na posição C-4 interage, apenas, com o resíduo Asn-H33. Outra característica do sítio ativo do anticorpo é que ele apresenta menos resíduos carregados com relação à enzima, sendo particularmente significativo para o ambiente do carboxilato em C10 e do oxigênio da função éter, o qual está carregado positivamente no sítio ativo $^{78}$. Apesar do menor número de interações entre cargas que estabilizam o estado de transição, o valor de $\Delta \mathrm{H}^{\#}$ medido é tão baixo quanto o valor observado para a 
enzima. Tal observação pode ser consequência da restrição do movimento dos grupos estabilizadores, a fim de se alcançar estabilização do estado de transição. Alternativamente, o corismato pode se ligar em uma conformação diequatorial de forma que, tanto a reação catalisada como a não catalisada apresentem o mesmo $\Delta \mathrm{S}^{\#}$ desfavorável. No entanto, Hilvert et. al. ${ }^{17,75,76}$ obtiveram evidências espectroscópicas, utilizando-se RMN de ${ }^{1} \mathrm{H}$ e NOE diferencial, para a ligação do corismato em uma conformação diaxial (Figura 5).

Diferentes grupos têm empregado métodos semi-empíricos no estudo desta reação ${ }^{79}$. Wiest e Houk ${ }^{78}$ exploraram o efeito de substituintes na reação, utilizando sistemas modelos, a fim de mimetizar a maneira pela qual o anticorpo e a enzima catalisam a reação. Foram aplicadas as teorias do funcional de densidade e de Hartree-Fock. Os resultados forneceram informações adicionais acerca da menor atividade catalítica observada para o anticorpo. Embora o sítio ativo também force o substrato a adquirir uma conformação similar a do estado de transição, as interações de ligação são muito mais fracas quando comparadas às da enzima. As interações com o oxigênio da função éter e o carboxilato da cadeia lateral, importantes para catálise segundo os cálculos efetuados, são os contatos com o esqueleto da proteína ${ }^{78}$. No anticorpo as cadeias laterais e grupos funcionais dos resíduos Asn-H33, Asp-H99 e Arg-H95 são direcionados para fora do sítio ativo. Portanto, não há grupos funcionais presentes no sítio ativo que possam fornecer complementaridade de carga ou aumento de ligações hidrogênio, fundamentais para a catálise. Ademais, uma melhora no anticorpo catalítico, através da mutagênese sítio-dirigida, requer mudanças conformacionais significativas para permitir a interação de grupos funcionais apropriados com os resíduos relevantes do estado de transição ${ }^{78}$.

Outro importante exemplo do uso de anticorpos como sequestradores entrópicos, são as reações de Diels-Alder entre um dieno e um alqueno para a formação de um ciclohexeno, com alta seletividade. Anticorpos catalíticos para cicloadições de Diels-Alder representam uma das conquistas mais importantes neste campo, não apenas por esta transformação ser frequentemente considerada como o processo mais importante de formação de ligação carbono-carbono, mas também, devido a sua habilidade em controlar a enâncio- e estereoseletividade da formação da ligação ${ }^{68,69,79,80}$.

Anticorpos que catalisam tais processos ampliam o alcance dos biocatalisadores conhecidos na enzimologia clássica, oferecendo novas oportunidades para a síntese orgânica ${ }^{81,82}$. A possibilidade de manutenção de dois reagentes juntos, no sítio ativo do anticorpo, através de interações de ligação, aumenta a probabilidade de reação. Assim, a perda de entropia rotacional e translacional durante a reação precisa ser compensada pela energia de ligação.

O estado de transição desta reação é altamente ordenado em um evento mecanístico concertado. Como resultado, uma entropia de ativação desfavorável é observada, e a geração de anticorpos deve levar em conta não só efeitos de proximidade, mas proporcionar um mecanismo que elimine a inibição pelos produtos da reação. Hilvert et. al. ${ }^{68}$ obtiveram sucesso com um sistema que satisfez ambos os critérios, a reação de dióxido de tetraclorotiofeno 1 com N-etilmaleimida 2 (Figura 1). Nesta reação, o produto dihidroftalimida $\mathbf{3}$ liga-se fracamente ao anticorpo e um significativo aumento na velocidade da reação foi conseguido, com múltipla frequência de transformação 68

Outra estratégia utilizada na catálise de reações Diels-Alder, envolveu a síntese de um hapteno contendo uma ponte etano, a qual mantém o anel de ciclohexano em uma conformação que se assemelha ao estado de transição da reação ${ }^{69}$. Já que o produto, ciclohexeno, não contém esta ponte hidrofóbica e apresenta uma conformação diferente do hapteno, ele deveria estar fracamente ligado pelo anticorpo, evitando inibição pelo produto. Os anticorpos produzidos contra este hapteno permi- tiram uma ligação do dieno acíclico em uma conformação cissyn reativa. Entretanto, uma afinidade pelo produto duas vezes maior do que pelos substratos, dieno e dienófilo, foi observada, além de uma baixa molaridade para o sistema, 0,35 $\mathrm{M}^{69}$.

A preparação de tais anticorpos é muito importante por várias razões. Estas moléculas são as primeiras proteínas catalisadoras de reações de cicloadição, permitindo a exploração de efeitos de proximidade para acelerar reações não fisiológicas. Além disso, tais princípios podem ser extendidos à outras transformações pericíclicas. Estes anticorpos são também candidatos atrativos para a ativação de pró-drogas in vivo, uma vez que não ocorrem interferências de enzimas que poderiam ocorrer naturalmente.

Recentemente, Bahr et. al. ${ }^{83}$ obtiveram um anticorpo catalítico, exibindo múltipla frequência de transformação, que promove uma reação retro-Diels-Alder liberando nitroxila (HNO), como um heterodienófilo; e antraceno, a partir de uma pró-droga inerte $\left(\mathrm{K}_{\mathrm{m}}=100 \mu \mathrm{M}, \mathrm{k}_{\text {cat }}=0,07 \mathrm{~min}^{-1}, \mathrm{k}_{\text {uncat }}=3 \mathrm{x}\right.$ $\left.10^{-4} \mathrm{~min}^{-1}\right)$. Desta forma, a nitroxila liberada pode ser oxidada a óxido nítrico (NO) pela enzima superóxido dismutase (SOD), presente nos sistemas biológicos. Este sistema de liberação de pró-drogas é de particular importância biológica, uma vez que o óxido nítrico atua como um mensageiro químico em vários processos biorreguladores fundamentais, incluindo regulação da pressão sanguínea e eventos associados à memória ${ }^{83}$. Neste caso, este sistema envolvendo anticorpo catalítico/SOD poderia, de certa forma, ser considerado como equivalente a uma NO-sintase.

Os experimentos mostraram que a reação catalisada é independente do $\mathrm{pH}$, sendo provavelmente mediada por interações entre os dois anéis fenílicos do substrato e o anticorpo. Foi também sugerido que fatores adicionais deveriam influenciar na catálise, por exemplo, interações eletrostáticas entre o anticorpo e o estado de transição com carga parcial negativa no átomo de oxigênio, ou ligações hidrogênio entre um resíduo no anticorpo e a ponte $\mathrm{HNO}^{83}$.

A relevância biológica da reação foi demonstrada pela produção seletiva e controlada de concentrações biológicas de óxido nítrico, na presença de superóxido dismutase ${ }^{83}$. Em geral, as drogas comumente empregadas como fonte de NO no tratamento de angina e hipertensão, por exemplo, nitroglicerina, se decompõem rapidamente, devendo ser administradas em altas doses, podendo, eventualmente, induzir tolerância. A liberação controlada de nitroxila em condições fisiológicas, oferece uma oportunidade única para o estudo direto de seus efeitos biológicos. O mais importante é que a velocidade e o local da liberação de nitroxila in vivo, poderiam ser controlados pela localização dos anticorpos catalíticos.

A formação de ligação carbono-carbono compreende o cerne da química orgânica sintética e da biossíntese. Uma reação amplamente empregada em síntese, é a condensação aldólica entre um enolato e um aldeído, formando a $\beta$-hidroxicetona correspondente (Figura 6a). As enzimas aldolases classe-1 catalisam especificamente esta reação, através de um mecanismo complexo, com a formação de um intermediário covalente enzima-substrato. A base de Schiff formada entre o resíduo Lys, no sítio ativo (19), e o substrato cetona (20), diminui a energia de ativação para a abstração do próton, formando a enamina. Adição desta enamina a um aldeído (21) é seguida pela hidrólise da base de Schiff e liberação da $\beta$-hidroxicetona (22), com regeneração do catalisador.

Catálise por anticorpos utilizando-se uma amina externa como cofator foi recentemente demonstrada, mas a necessidade deste cofator externo limitou a eficiência catalítica que poderia ser atingida ${ }^{84}$. Recentemente, foi demonstrado que um hapteno dicetônico é capaz de formar uma base de Schiff com um resíduo Lys no anticorpo, que em seguida tautomeriza, formando a amida estável (Figura 6b). Neste caso, o hapteno 23 induziu à formação de anticorpos com uma amina cataliticamente ativa no sítio-combinante. A velocidade da reação catalisada foi $>10^{9}$ vezes a da reação não catalisada ${ }^{19}$. 
(a)

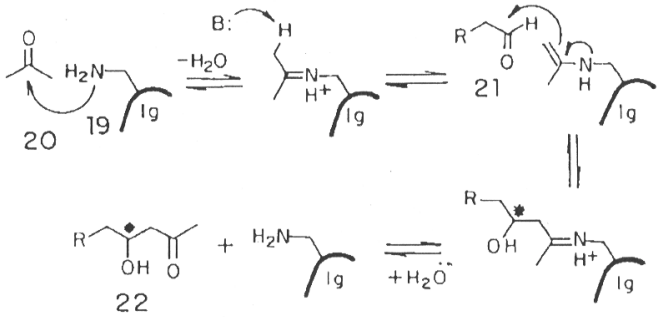

(b)

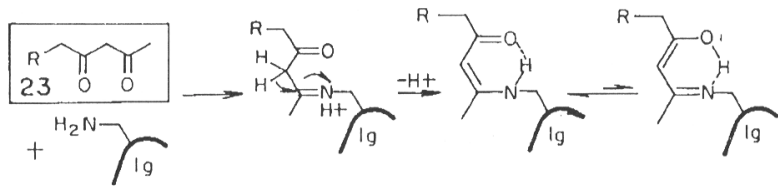

Figura 6. Catálise por anticorpos de uma condensação de Aldol através da formação de uma base de Schiff. (a) Formação da base de Schiff entrea cetona 20 e um sítio ativo Lys da cadeia lateral do anticorpo (lg), e subseqüente formação de um novo centro quiral (22), com regeneração do catalisador. (b) O hapteno 23 pode formar uma base de Schiff com um resíduo Lys do anticorpo e subseqüentemente tautomerizar para formar uma amida estável. Este hapteno é utilizado para produzir anticorpos com uma amina cataliticamente ativa no sítio combinante.

O anticorpo 33F12 em particular, catalisou a condensação da acetona com 2-fenilpropionaldeído estereoseletivamente. A adição catalisada da enamina ocorre, preferencialmente, à face $\mathrm{Si}$ do aldeído, formando $\beta$-hidroxicetonas com alto excesso diastereomérico $(>95 \%)^{19}$. Em alguns casos, a preferência estereoquímica inerente da reação é revertida, e o produto normalmente desfavorecido é obtido com um excesso diastereomérico da ordem de $83 \%$.

Koch et. al. ${ }^{85}$ reportaram a primeira condensação de Aldol intramolecular catalisada por anticorpos que procede através da estabilização sequencial de três estados de transição distintos (Figura 7). A condensação intramolecular do cetoaldeído $\mathbf{2 4}$ forneceu uma 2-benzil-3-hidroxiciclohexanona substituída (25), que através de uma eliminação desfavorecida produziu 2-benzil2-ciclohexenona $(\mathbf{2 6})^{85}$. A sequência envolve quatro etapas individuais de reação, sendo que três delas podem ser aceleradas empregando-se catálise ácido-base geral, com transferência de próton próxima ou no carbono- $\alpha$ da cetona envolvida na condensação. $\mathrm{O}$ anticorpo $78 \mathrm{H} 6$, produzido contra o hapteno $\mathrm{N}$ benzil-N-metilpiperidínio (estrutura 27), foi capaz de catalisar três das quatro etapas sequenciais da reação (Figura 7, etapas A, $\mathrm{C}$ e D $)^{85}$. Este anticorpo parece agir puramente como uma base geral, através de um resíduo carboxílico, sendo seletivo para a eliminação-trans desfavorecida (estereoisômero 25a). O anticorpo é aproximadamente $2 \times 10^{5}$ vezes mais reativo do que acetato para a catálise ${ }^{85}$. Estes experimentos demonstram que a catálise de reações com estados de transição consecutivos é igualmente possível utilizando-se anticorpos catalíticos

\section{INTRODUÇÃO DE GRUPOS CATALÍTICOS EM SÍTIOS COMBINANTES DE ANTICORPOS}

Uma estratégia pela qual grupos catalíticos podem ser introduzidos em sítios combinantes de anticorpos é a modificação química seletiva com catalisadores naturais ou sintéticos, como complexos de metais de transição, cofatores, bases ou nucleófilos. Enzimas podem ser seletivamente modificadas por cofatores, e esta técnica vem sendo aplicada aos anticorpos, combinando-se a especificidade requintada do sistema imune aos diversos catalisadores disponíveis na química sintética ${ }^{86}$. Este método não requer conhecimento prévio da estrutura tridimensional do anticorpo, podendo ser aplicado a inúmeras proteínas.

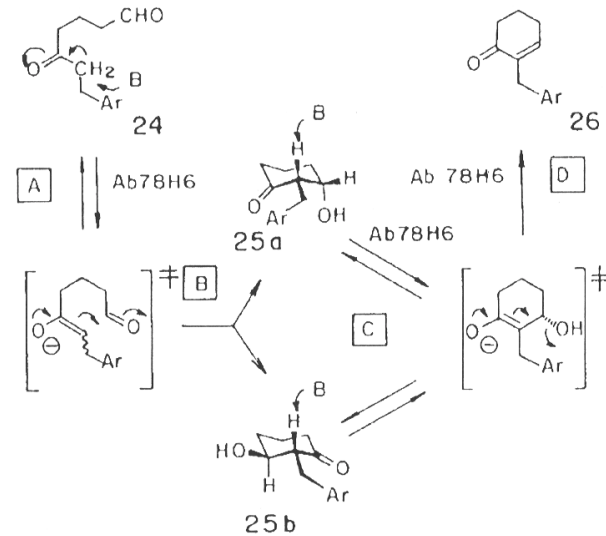

Figura 7. Condensação de Aldol do ceto-aldeído 24 aos aldóis 25 a, $b$ e à enona 26. O anticorpo $78 H 6$ catalisa três das quatro etapas individuais envolvidas no processo $(A, C$ e $D)$. * $* B=$ anticorpo.<smiles>C[N+]1(CBr)CCC[C@@H](CNC(=O)[O-])C1</smiles>

27

Estrutura 27

Por exemplo, o anticorpo MOPC315 foi seletivamente modificado com a introdução de um grupo tiol nucleofílico em seu sítio combinante, mais especificamente no resíduo Lys-H52. $\mathrm{O}$ grupo tiol foi apropriadamente posicionado para agir na tiólise do éster cumarina. A velocidade da reação catalisada pelo anticorpo modificado foi $6 \times 10^{4}$ vezes mais rápida comparada ao uso de ditiotreitol ${ }^{86}$. O grupo tiol também pode ajudar na introdução de outra funcionalidade química no sítio combinante do anticorpo. Por exemplo, o imidazol foi incorporado com um rendimento maior do que 90\% (Figura 8). O anticorpo semi-sintético resultante catalisou a hidrólise do éster cumarina (Figura 8, estrutura 28) com uma velocidade $10^{3}$ vezes mais rápida do que a catálise por 4 -metil imidazol ${ }^{86}$.
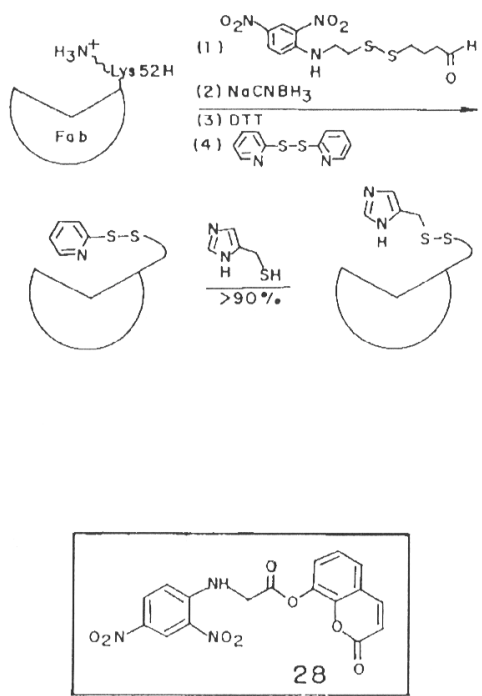

Figura 8. Modificação do fragmento Fab do anticorpo MOPC 315 pela introdução de um anel imidazol no sítio de ligação. A estrutura 28 corresponde ao éster cumarina utilizado como substrato da reação de hidrólise. 
Outra ferramenta importante utilizada é o método biológico de mutação sítio-dirigida. Neste caso, a estrutura tridimensional do anticorpo é necessária para determinar qual o sítio de modificação. Esta técnica foi aplicada para a introdução de His catalíticas nos sítios ativos específicos para dinitrofenil (anticorpo S107) e fosforilcolina (anticorpo MOPC315). Os anticorpos resultantes mostraram atividade estereolítica maior do que $10^{5}$ vezes comparada à reação catalisada por imidazol ${ }^{49}$.

Uma terceira estratégia envolve a geração de um sítio de ligação para um cofator natural ou sintético, além do sítio de ligação do substrato. Anticorpos gerados especificamente para flavinas ligam-se com uma afinidade $4 \times 10^{4}$ vezes maior em relação à 1,5-dihidroflavina, devido as diferentes propriedades conformacionais e eletrônicas ${ }^{87}$. Esta estabilização diferencial das formas oxidada e reduzida do cofator pelo sítio combinante do anticorpo, faz com que o complexo anticorpo-1,5dihidroflavina seja um agente redutor mais forte em solução. $\mathrm{O}$ potencial de redução da flavina ligada ao anticorpo é $-342 \mathrm{mV}$, representando uma diminuição de $5 \mathrm{kcal} / \mathrm{mol}$ no potencial de redução $\left(E_{m}=-206 \mathrm{mV}\right)$. Desta forma, o complexo foi capaz de reduzir rapidamente o substrato safranina $\mathrm{T}\left(\mathrm{E}_{\mathrm{m}}=-289\right.$ $\mathrm{mV})^{87}$. Tais anticorpos são importantes quando se consideram reduções químicas estereocontroladas.

Numerosos exemplos de enzimas capazes de mediar reações redox são conhecidos. Estas enzimas utilizam cofatores redox biológicos, flavina, nicotinamida e o grupo heme. Anticorpos têm sido obtidos para a catálise de reações redox, utilizando cofatores redox, versáteis e inexpressivos, não encontrados na natureza.

O anticorpo 28B4.2 catalisou a oxigenação-dependente de periodato de um sulfeto ao sulfóxido correspondente com um $\mathrm{k}_{\text {cat }}=8,2 \mathrm{~s}^{-188}$. O anticorpo foi obtido utilizando-se um hapteno contendo um grupo fosfonato para fornecer um sítio de ligação para o oxidante químico, periodato, enquanto que a amina carregada positivamente deve mimetizar a carga positiva incipiente do átomo de enxofre no estado de transição. A frequência de transformação e o aumento da velocidade da reação catalisada por este anticorpo são comparáveis aos de muitas monoxigenases. Além disso, não foi observada inativação como resultado da oxidação do anticorpo ${ }^{88}$. A catálise de outra reação de oxidação por anticorpos, a epoxidação de olefinas desfuncionalizadas, também ocorre utilizando-se um oxidante químico relativamente barato, o peróxido de hidrogênio ${ }^{89}$.

Outro exemplo interessante, é a ligação de anticorpos a metais como cofatores na catálise da ligação Gly-Phe de um peptídeo como substrato em $\mathrm{pH}$ neutro ${ }^{47}$. Este trabalho é o ponto de partida para a obtenção de peptidases de sequências específicas, como as enzimas de restrição equivalentes para proteínas.

\section{REAÇÕES QUÍMICAS DESFAVORECIDAS CATÁLISADAS POR ANTICORPOS}

Em muitas reações, tais como Diels-Alder e ciclizações intramoleculares, a razão entre produtos pode ser estudada em termos das características estereoeletrônicas dos estados de transição favorável e desfavorável (por exemplo, cicloadição exo x endo, substituição nucleofílica 5-exo x 6-endo). Na prática é difícil discriminar quimicamente e controlar as energias relativas dos estados de transição. Por exemplo, formar o aduto exo na reação de Diels-Alder ou o produto anti-Baldwin em um fechamento de anel. Como enzimas, os anticorpos são capazes de utilizar a energia de ligação para estabilizar seletivamente um dos muitos estados de transição isoenergéticos, levando à produção de um único produto em lugar de uma mistura de produtos. Alternativamente, anticorpos podem estabilizar seletivamente um estado de transição de alta energia, permitindo a formação de um produto desfavorável, antes não observado. Exemplos de tais reações incluem reduções estereo- e regioespecíficas ${ }^{90}$, reações de hidrólise ${ }^{91}$, bem como a partição de intermediários reativos em caminhos de reação normalmente desfavorecidos ${ }^{92,93}$.
Um dos principais objetivos da catálise por anticorpos é fornecer reagentes que sejam úteis em síntese orgânica. Oxepanos é uma das estruturas encontradas em muitas substâncias ativas biologicamente ${ }^{94}$. Uma nova rota sintética para a síntese de oxepanos desfavorecidos pela regra de Baldwin, a partir do epóxi-álcool correspondente (Figura 9, estrutura 29), foi proposta por Janda et. $a l .{ }^{95,96}$. O anticorpo 26D9, utilizado, inicialmente, na obtenção do tetrahidropirano desfavorável (produto 6-endo; estrutura 32), preferencialmente ao produto 5-exo (estrutura 33), foi obtido contra um hapteno (Figura 10) especificamente desenhado para induzir propriedades críticas do estado de transição limitantes da velocidade da reação de fechamento de anel do epóxido $\mathbf{3 1}^{96}$. A conformação cadeira adquirida pelo substrato durante o fechamento do anel foi estabilizada por um anel piperidínio; uma função $\mathrm{N}$-óxido foi introduzida para mimetizar o desenvolvimento de carga esperado no estado de transição e, desta forma, induzir complementaridade de carga no anticorpo provocando uma diminuição na energia da reação. Ademais, a diferença de carga entre o hapteno e o produto da reação catalisada (produto anti-Baldwin) deveriam minimizar a inibição pelo produto ${ }^{96}$. A idéia central deste trabalho foi demonstrar que a catálise por anticorpos é relativamente indiferente a alguns componentes estruturais do substrato, como, por exemplo, o comprimento da cadeia metilênica responsável pela incorporação do anel, enquanto que, parâmetros mecanísticos permaneceriam constantes ${ }^{95}$. Desta forma, sínteses de éteres cíclicos maiores e, portanto, mais difíceis seriam possíveis utilizando-se catálise por anticorpos. De fato, quando catalisada pelo anticorpo 26D9, a abertura do anel epóxido ocorre praticamente com total controle regioseletivo, sendo o produto 7-endo formado com $98 \%$ de rendimento e excesso enanciomérico de $78 \%$ (Figura 9 , estrutura 30b) $)^{95}$.

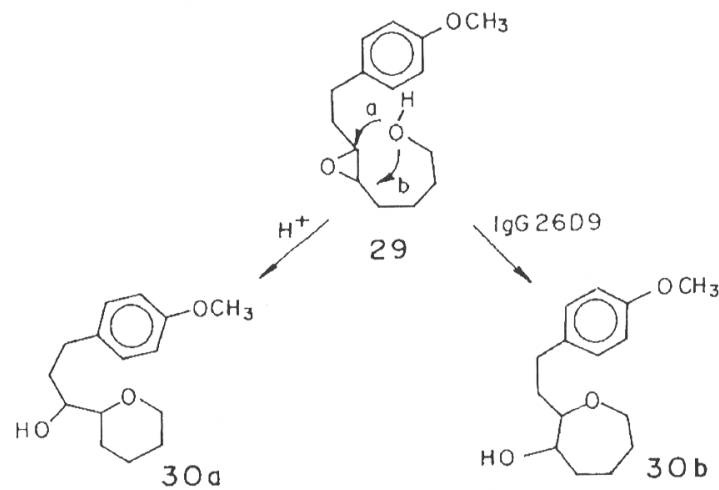

Figura 9. Catálise ácida e catálise pelo anticorpo $26 D 9$ ( $\lg G 26 D 9)$ da reação de fechamento de anel do epóxido 29, com formação dos produtos 6-exo (30a) e 7-endo (30b), respectivamente.

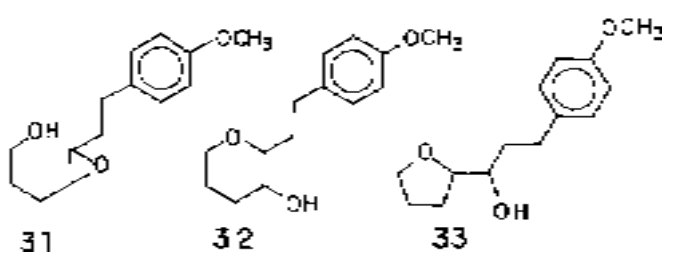

Estruturas 31-33.

Estes resultados demonstram como bibliotecas de moléculas combinantes e princípios de reatividade química podem ser utilizados em conjunto para gerar novos catalisadores capazes de redirecionar reações químicas. É importante ressaltar que, uma vez que o catalisador é induzido pelo experimentador, uma previsão da possível distribuição da energia de ligação é mais provável do que no caso de enzimas que evoluem naturalmente. 
<smiles>CCCCCC[N+](=O)Cc1ccc(NC(=O)CCCC(C)=O)cc1</smiles><smiles>CCCCCC(=O)[C@H](O)CCc1ccc(OC)cc1</smiles>

Figura 10. Comparação entre as estruturas do hapteno utilizado na obtenção do anticorpo $26 \mathrm{D9}$, e do possível estado de transição da reação de fechamento do anel.

Neste experimento especificamente, o conhecimento prévio das ligações envolvidas, permitiu uma escolha inteligente de substratos alternativos. A utilização de uma única enzima para múltiplos substratos, de maneira racional, é quimicamente atraente, pois permite a associação entre a enzima e o substrato com base em interações de ligação detalhadas e não ao acaso.

Um outro exemplo de seleção do estado de transição por um anticorpo catalítico é a eliminação syn de uma $\beta$ fluorocetona (34) produzindo uma olefina cis (35b) (Figura $11)^{97}$. Em condições normais, o mecanismo cineticamente favorecido é a eliminação antiperiplanar da conformação alternada. Nesta conformação, os grupos fenil e benzoil volumosos estão espacialmente distantes, e a eliminação de HF produz a olefina trans 35a.

O anticorpo 1D4 foi capaz de estabilizar a conformação eclipsada, levando à eliminação syn, com a formação exclusiva do produto cis $\mathbf{3 5} \mathbf{b}^{97}$. O hapteno 36 foi desenhado com um sistema de anéis bicíclicos para fornecer um esqueleto rígido, que representa os substituintes fenil e benzoil na conformação eclipsada desejada. Uma amina primária foi introduzida na posição correspondente à do próton ácido do substrato a fim de induzir um grupo carboxilato complementar no sítio combinante do anticorpo. Desta forma, o carboxilato poderia agir como uma base geral (Figura 11) ${ }^{97}$.

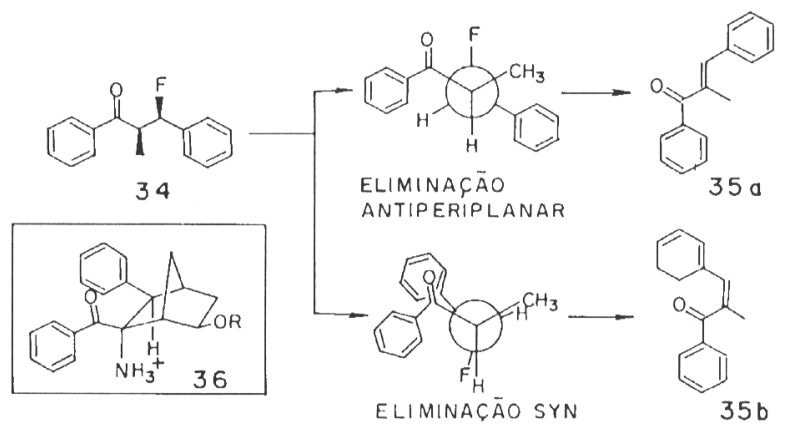

Figura 11. Eliminação antiperiplanar e eliminação syn da fluorocetona 34 em solução aquosa e na presença do anticorpo produzido contra o hapteno 36 , respectivamente.

Muitas transformações químicas importantes ocorrem através de intermediários altamente reativos. A habilidade de enzimas em sequestrar tais intermediários da solução e permitir que determinadas reações ocorram, torna possível a biossíntese de muitas moléculas complexas. Diferentes anticorpos foram capazes de catalisar reações de transferência de grupo acil a outros nucleófilos que não a água, indicando que, como enzimas, anticorpos podem efetivamente excluir a água e, certamente, outros substratos indesejáveis da reação ${ }^{70,98}$. Recentemente, um anticorpo foi utilizado para catalisar a transformação intramolecular de um enol-éter protonado em um cetal. Na ausência do anticorpo, o intermediário oxicarbônio reage apenas com a água para produzir a cetona ${ }^{92}$.

Além destes exemplos, a catálise por anticorpos têm sido utilizada em síntese estereoseletiva de oximas para gerar o produto anti desfavorecido ${ }^{99}$, redução regio- e estereoseletiva de dicetonas para produzir predominantemente ( 95\%) um dos oito produtos possíveis ${ }^{90}$; e protonação estereoespecífica de enol-éteres, levando aos produtos de hidrólise quiral ${ }^{60}$. Catálise por anticorpos foi utilizada para a hidrólise estereoseletiva de um enol-éter em grande escala, inserindo-se um estereocentro chave na síntese da (-)- $\alpha$-multistriatina ${ }^{82}$.

Da mesma forma que na reação de Diels-Alder, o rearranjo oxi-Cope, um rearranjo [3,3]-sigmatrópico, procede através de um estado de transição altamente ordenado ${ }^{100,101}$. Braisted e Schultz ${ }^{100}$ demonstraram que anticorpos gerados contra um hapteno (Figura 12, estrutura 40) que mimetiza a geometria tipo cadeira do estado de transição da reação, catalisam o rearranjo oxi-Cope com um aumento na velocidade da reação da ordem de 5000 vezes (Figura 12).

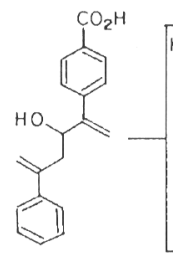

37
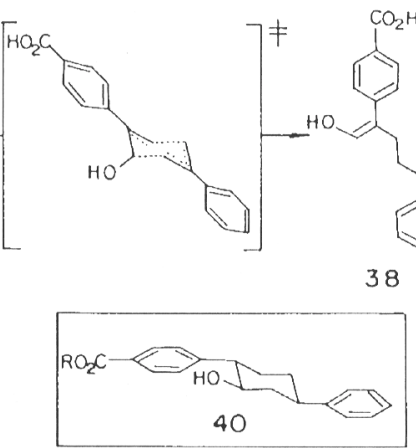

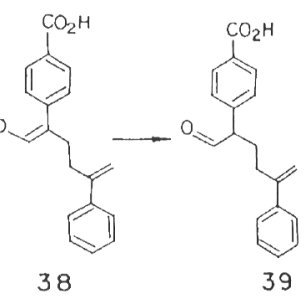

39
Figura 12. Rearranjo oxi-Cope do substrato 37, fornecendo o enol 38 que rapidamente tautomeriza formando o aldeído 39. O hapteno 40 foi utilizado para a obtenção de anticorpos que aceleram a velocidade da reação.

Embora não haja limites óbvios para o alcance das reações que podem ser catalisadas por enzimas, para muitas classes de reações, entretanto, catalisadores naturais específicos não são conhecidos. Para tais reações a utilização de anticorpos catalíticos será uma alternativa promissora.

\section{CONCLUSÕES}

A aumentada sofisticação no desenho de haptenos têm resultado na produção de anticorpos catalíticos com complexidade e eficiência comparável ou ainda superior que a observada para enzimas. $\mathrm{O}$ resultado tem sido anticorpos que catalisam reações não encontradas na natureza ou aquelas difíceis de serem catalisadas utilizando-se os métodos químicos existentes. Em combinação com estes estudos, o aumento no número de informações estruturais promete contribuir grandemente à compreensão da catálise biológica, bem como à capacidade de produção de anticorpos catalíticos altamente sofisticados $42,51,53,55,76,102$. Anticorpos catalíticos já estão sendo utilizados em laboratórios como uma ferramenta em síntese orgânica, e o próximo passo, sua utilização em ciclos de produção, dependerá unicamente da assimilação criativa de idéias em química, imunologia, bioquímica de proteínas e biologia molecular. Além disso, o aumento da eficiência catalítica irá afetar criticamente a extensão da aplicação desta metodologia em medicina. Por exemplo, desde o reconhecimento do potencial dos anticorpos catalíticos como ativadores de pró-drogas ${ }^{103}$, vários grupos têm isolado anticorpos com eficiência catalítica suficiente para a aplicação como 
agentes terapêuticos na ativação de pró-drogas em produtos tóxicos, particularmente na terapia do câncer, ou mesmo em processos de destoxificação ${ }^{83,104}$. O que é particularmente notável, entretanto, é o fato de uma proteína simples, com a mesma estrutura secundária e terciária, poder ser adaptada para acomodar diferentes tipos de reações, com diversificada eficiência para aplicações em química, biologia e medicina.

\section{GLOSSÁRIO}

afinidade: medida da força de ligação entre o determinante antigênico (epítopo) e o sítio combinante do anticorpo.

afinidade de maturação: aumento na afinidade média de anticorpos frequentemente observada durante uma resposta imune secundária.

aminoácidos

His: histidina

Tyr: tirosina

Ser: serina

Cys: cisteína

Phe: fenilalanina

Arg: arginina

Asn: asparagina

Asp: ácido aspártico

Lys: lisina

Gly: glicina

anticorpo: molécula protêica solúvel produzida pelas células plasmáticas em resposta à antígenos e capaz de ligar-se especificamente ao antígeno que induziu a sua formação.

anticorpo monoclonal: anticorpos produzidos a partir de um único clone, os quais são homogêneos. O termo policlonal descreve os produtos de inúmeros tipos celulares diferentes.

anticorpo policlonal: uma mistura de anticorpos específicos para um determinado antígeno, os quais apresentam diferentes afinidades pelo antígeno específico, dependendo primariamente da sequência de aminoácidos precisa das regiões de complementaridade. Em geral, antígenos naturais contêm mais do que um determinante e, portanto, ligam-se a mais do que uma molécula de anticorpo.

antígeno: um agente que é estranho (i.e., "não-próprio") a um animal e que é reconhecido pelo sistema imune.

bacteriófago $\lambda$ ou fago $\lambda$ : um vírus que replica utilizando a bactéria como um hospedeiro. Particularmente empregado como vetor (ou transportador) para a introdução de genes estranhos no genoma da $E$. coli, na tecnologia do DNA recombinante. Desde que o fago $\lambda$ é um fago temperado, o seu DNA pode tornar-se incorporado no cromossomo da E. coli, junto com o gene estranho que ele carrega. Neste caso, o DNA $\lambda$ e o gene estranho serão replicados em cada ciclo da divisão celular.

cadeia leve e cadeia pesada: a estrutura da molécula de anticorpo é formada por duas cadeias leves idênticas, cada uma com um PM de aproximadamente $24 \mathrm{kDa}$, e duas cadeias pesadas idênticas de aproximadamente 55 a $70 \mathrm{kDa}$. Cada uma das cadeias leves está ligada a uma cadeia pesada, enquanto que as duas cadeias pesadas são mantidas unidas entre si por pontes de dissulfeto. Ambas as cadeias, leve e pesada, contêm uma série de unidades repetidas homólogas, de aproximadamente 110 resíduos de aminoácidos em comprimento, que se dobram independentemente adquirindo uma forma globular.

cDNA: um DNA cópia complementar à sequência de mRNA transcrita de um dado gene ou genes. Portanto, o cDNA irá hibridizar com estes genes e, quando radiomarcado, permitirá sua detecção em cromossomos (hibridização in situ) ou em DNA ou mRNA extraídos de células e separados por eletroforese (processos conhecidos como "Southern" e "Northern blots" respectivamente).

células B: subsérie de linfócitos precursores das células plasmáticas produtoras de anticorpos e que expressam uma molécula de anticorpo na superfície. células esplênicas: células provenientes do baço.

clone: (a) um grupo de células derivadas de uma única célula. (b) uma família de células ou organismos que apresentam uma constituição geneticamente idêntica.

cofator: um assessor enzimático que se liga a uma enzima assistindo na ativação ou desativação do sítio de ligação. Cofatores podem ser tão complexos quanto moléculas orgânicas, ou tão simples quanto íons metálicos.

complemento (C1-C9): componentes das vias clássica e lítica do complemento (moléculas protêicas), responsáveis por mediar reações inflamatórias, opsonização de partículas e lise de membranas celulares.

DNA recombinante: método altamente especializado de produção de cópias exatas de uma substância. O DNA de certas células pode ser trocado ou adicionado, tornando-se "fábricas" de produção de uma determinada substância desejada. A tecnologia do DNA recombinante é usualmente empregada para a obtenção de grandes quantidades de substâncias presentes no organismo, tais como, insulina, interferons e fatores de estimulação de crescimento e diferenciação celular.

ELISA (Enzyme Linked Immuno Absorbent Assay): um conjunto de técnicas de alta sensibilidade e especificidade para a medida dos níveis de antígeno ou anticorpo, nas quais um dos reagentes é acoplado a uma enzima produzindo um produto de reação colorido. Este método requer a disponibilidade de uma molécula indicadora da quantidade da substância, um anticorpo que é ligado covalentemente à enzima. Desta forma pode-se quantificar a substância de interesse através da medida da atividade da enzima, ou seja, a velocidade inicial na qual a enzima converte um substrato incolor em um produto colorido.

epítopo: um único determinante antigênico. Funcionalmente é a porção do antígeno que combina com o anticorpo.

fago filamentoso: recombinante derivado do bacteriófago $\lambda$ que expressa o produto recombinante (por exemplo, a molécula de anticorpo) associado ao envelope protêico externo da partícula viral. Além disso, é facilmente liberado ao meio externo sem provocar a lise da célula hospedeira (em geral, bactéria).

fago temperado ou lisogênico: espécie de fago que pode incorporar o seu DNA no cromossomo da célula hospedeira em uma forma não expressável. O DNA de certas espécies de fagos, quando infectam uma célula bacteriana, pode se tornar covalentemente incorporado no cromossomo circular da célula hospedeira, ao invés de levar à imediata propagação das partículas virais-filhas e à subsequente lise das células, como é usual no caso de infecções virais. Uma vez que o genoma viral foi incorporado no cromossomo hospedeiro, ele pode replicar por muitas gerações, sem ser expresso na forma de partículas virais. Entretanto, posteriormente, algum evento particular pode desengatilhar a expressão destes genes virais dormentes, causando a formação da progênie viral e lise da célula.

fragmento $\boldsymbol{F a b}$ : parte da molécula de anticorpo que contém o sítio combinante de antígeno, consistindo da cadeia leve e parte da cadeia pesada. É produzido por digestão enzimática.

fragmento $\boldsymbol{F c}$ : porção da molécula de anticorpo responsável pela ligação aos receptores de anticorpos nas células e ao componente $\mathrm{C} 1 \mathrm{q}$ do complemento.

frequência de transformação ("Turnover"): número de moléculas de substrato transformadas por unidade de tempo por uma única molécula de enzima (ou por um único sítio catalítico) quando a concentração de enzima é o único fator limitante da velocidade da reação.

globulinas: glicoproteínas presentes no soro ou plasma, as quais podem ser posteriormente separadas por eletroforese em subgrupos. Os anticorpos pertencem, em sua grande maioria, ao subgrupo das gama-globulinas, sendo conhecidos também como imunoglobulinas.

hapteno: uma molécula pequena que pode atuar como um epítopo, mas que é incapaz de induzir à formação de um anticorpo ela própria. 
hibridização: (a) fusão de duas células somáticas para formar uma célula única. (b) ligação de sequências complementares (homólogas) de DNA ou RNA. Tais ligações complementares podem ter lugar sob diferentes condições (grau de severidade) que ditam a extensão da homologia requerida para que a ligação ocorra. O termo refere-se à ligação de uma sonda de DNA ou RNA marcado a uma colônia teste, tecido ou gel, para determinar se o gene ou mRNA em questão está presente.

hibridoma: linhagens celulares geradas in vitro pela fusão de dois tipos celulares diferentes, usualmente linfócitos, um dos quais uma célula tumoral. Tal termo é frequentemente utilizado para descrever populações de células híbridas que produzem anticorpos monoclonais. Esta célula é o produto da fusão de uma célula normal-produtora de anticorpos e uma célula tumoral-não-secretora de anticorpos (mieloma).

homólogo: da mesma espécie.

imortalização: processo que permite que células formem uma linhagem celular contínua (isto é, capazes de proliferar indefinidamente) em cultura. Células normais proliferam por um número limitado de passagens em cultura, sendo que imortalização parece ser uma etapa necessária, mas não suficiente, para a transformação a um estado maligno.

imunidade: resistência à infecção. Existem duas formas principais: imunidade Natural (ou passiva) e imunidade Adaptativa. imunógeno: moléculas capazes de gerar uma resposta imune. mieloma: um linfoma derivado de células pertencentes à linhagem das células B. Tais células fequentemente secretam níveis altos de anticorpos bioquimicamente idênticos ou porções de anticorpos que fornecem uma fonte de moléculas de anticorpos de especificidade única. Tais tumores ocorrem espontaneamente em humanos e podem ser induzidos experimentalmente em camundongos.

mutação: uma mudança em uma ou mais bases do DNA de um gene. As alterações podem incluir a inserção ou a deleção de uma ou mais bases. Alterações nas regiões codificadoras do DNA (exons) levam a produtos protêicos alterados; mutações em regiões não-codificadoras podem levar a quantidades alteradas de uma dada proteína.

mutação sítio dirigida: uma técnica utilizada para introduzir uma mudança na sequência de um sítio específico de um dado DNA. PCR (polymerase chain reaction): um método pelo qual um dado segmento de DNA ou RNA é amplificado múltiplas vezes pela síntese contínua de fitas complementares. O processo ocorre de maneira cíclica em três etapas: desnaturação, anelamento e extensão.

proteína carreadora: de maneira a se obter anticorpos específicos a um determinado hapteno, tais moléculas pequenas são, frequentemente, ligadas a macromoléculas previamente ao processo de imunização. Tais macromoléculas são, em geral, proteínas, sendo conhecidas como carreadoras. O complexo hapteno-carreador, ao contrário do hapteno livre, pode atuar como um imunógeno.

recombinação gênica: a diversidade das moléculas de anticorpo é o resultado da recombinação ou rearranjo de fragmentos de DNA codificadores das cadeias leve e pesada, as quais encontram-se em cromossomos diferentes nas células embrionárias. Nas células comprometidas com a síntese de anticorpos, isto é, os linfócitos B, os fragmentos de genes são unidos em um mesmo cromossomo, obedecendo uma sequência precisa durante o processo de maturação. Devido a diversidade de combinações possíveis, as moléculas de anticorpos apresentam uma maior diversidade na união das regiões $\mathrm{V}$ e $\mathrm{C}$ em ambas as cadeias leve e pesada.

região hipervariável: corresponde às sequências de aminoácidos altamente divergentes presentes na porção distal das regiões variáveis das imunoglobulinas. Em uma imunoglobulina intacta as três regiões hipervariáveis da cadeia leve e as três regiões hipervariáveis da cadeia pesada podem ser mantidas unidas em um espaço tridimensional para formar uma região de ligação de antígeno. Uma vez que estas sequências formam uma superfície complementar à superfície tridimensional de um antígeno ligado, as regiões hipervariáveis são conhecidas como regiões determinantes de complementaridade ou regiões combinantes ligantes.

região variável: corresponde às sequências de aminoácidos pertencentes ao domínio amino-terminal das cadeias leve e pesada. A região constante corresponde ao segmento de aminoácidos restante mais conservado destas cadeias e não contribuem ao sítio de ligação de antígeno.

resposta imune: resposta coordenada e coletiva do sistema imune contra substâncias estranhas.

resposta imune secundária: a resposta imune que se segue após um encontro secundário ou subsequente com um antígeno em particular.

sistema imune: conjunto de células e moléculas responsáveis pela imunidade.

soro policlonal: sobrenadante de sangue coagulado contendo uma mistura de anticorpos. Uma amostra de soro que contém um grande número de moléculas de anticorpos que se ligam a um antígeno em particular é chamada de anti-soro.

$t_{1 / 2}$ : tempo de meia vida

tolerância: um termo utilizado em imunologia para descrever o processo no qual não se observa uma resposta imunológica específica.

\section{ADENDUM}

Durante o processo de publicação desta revisão dois trabalhos de particular significância foram produzidos: 1) Janda, K. D.; Lo, L.-C.; Lo, C.-H. L.; Sim, M.-M.; Wang, R.; Wong, C.H.; Lerner, R. A.; Science 1997, 275, 945. Nos últimos anos a utilização de bibliotecas de moléculas como ferramenta em química expandiu rapidamente; e o sistema imune aparece como um dos sistemas combinatórios conhecidos mais importantes para a diversificação das moléculas ligantes. Entretanto, sua capacidade só será totalmente explorada em sistemas que permitam a seleção direta de uma função em particular. Neste recente trabalho, Janda et. al. publicaram uma nova metodologia que permite a seleção química direta para catálise a partir de bibliotecas de anticorpos. O modelo foi demonstrado para a clivagem de ligação glicosídica, podendo ser estendido a qualquer sistema combinatório replicante, no qual uma espécie reativa é formada durante a transformação química. $\mathrm{O}$ método preserva os aspectos positivos da tecnologia do hibridoma, mas o sistema foi adaptado no fago filamentoso para permitir um aumento no tamanho e na diversidade das bibliotecas combinatórias, com capacidade de seleção direta para a reatividade química. Um ligante multifuncional foi utilizado contendo três funções essenciais: 1) acoplamento do substrato a várias proteínas e matrizes poliméricas; 2) captação covalente dos clones catalíticos; e 3) recuperação do fago imobilizado, com retenção da sua capacidade de replicação. Desta forma, a frequência de transformação é preservada, permitindo seleção para catálise em lugar de reatividade estequiométrica.

2) Charbonnier; J.-B.; Golinelli-Pimpaneau, B.; Gigant, B.; Tawfik, D. S.; Chap, R.; Schindler, D. G.; Kim, S.-H.; Green, B. S.; Eshhar, Z.; Knossow, M.; Science 1997, 275, 1140. Neste trabalho foi comparado o poder de catálise em uma família de anticorpos, ao invés de demonstrar um evento singular através de uma única estrutura. As estruturas de raio-x de três anticorpos catalíticos com atividade esterase, identificados em um repertório inteiro de hibridomas, foram analisadas. Apesar das diferenças conformacionais significativas entre os sítios combinantes, os três anticorpos promoveram catálise essencialmente da mesma maneira, sugerindo que a evolução para ligação ao análogo do estado de transição, seguida pela seleção para catálise fornece anticorpos com convergência estrutural. Evolução convergente é um resultado frequente do processo de 
seleção natural e, até o presente, pouco é conhecido acerca deste processo, particularmente com relação às proteínas e suas funções. Estes experimentos sugerem que, com relação ao que se tem observado para enzimas, os sítios combinantes destes anticorpos resultam de evolução convergente, embora em tempo real e envolvendo uma porção limitada da proteína. Este trabalho certamente contribui como um ponto de partida para o refinamento das vias mecanísticas importantes nos processos catalíticos, ou seja, quais componentes do mecanismo catalítico deveriam ser mantidos, quais deveriam ser descartados e quais poderiam ser modificados. De certa forma, parece possível promover evoluções sucessivas através de ciclos alternados entre mutagênese e seleção.

\section{REFERÊNCIAS}

1. Davies, D. R.; Chacko, S.; Acc. Chem. Res. 1993, 26, 421.

2. Male, D.; Cooke, A.; Owen, M.; Trowsdale, J.; Champion, B.; Advanced Immunology; Mosby; London, 1996.

3. Pauling, L.; Am. Sci. 1948, 36, 519.

4. Jencks, W.; Catalysis in Chemistry and Enzymology; McGraw-Hill; New York, 1969.

5. Raso, V.; Stollar, B. D.; Biochemistry 1975, 14, 584.

6. Raso, V.; Stollar, B. D.; Biochemistry 1975, 14, 591.

7. Köhler, G.; Milstein, C.; Nature 1975, 256, 5517.

8. Köhler, G.; Houe, S. C.; Milstein, C.; Eur. J. Immunol. 1976, 6, 292.

9. Köhler, G.; Milstein, C.; Eur. J. Immunol. 1976, 6, 511.

10. Pollack, S. J.; Jacobs, J. W.; Schultz, P. G.; Science 1986, 234, 1570.

11. Tramontano, A.; Janda, K. D.; Lerner, R. A.; Science 1986, 234, 1566.

12. Schultz, P.; Angew. Chem. Int. Ed. Engl. 1989, $28,1283$.

13. Lerner, R. A.; Benkovic, S. J.; Schultz, P. G.; Science 1991, 252, 659.

14. (a) Powell, M. J.; Hansen, D. E.; Protein Eng. 1989, 3, 69; (b) Krafft, G. A.; Wang, G. T.; Ann. Rep. Med. Chem. 1989, 25, 299; (c) Schultz, P. G.; Acc. Chem. Res. 1989, 22, 287; (d) Shokat, K. M.; Schultz, P. G.; Ann. Rev. Immunol. 1990, 8, 335; (e) Hilvert, D.; Hill, K. W.; Meth. Enzimol. 1991, 203 , 352; (f) Suckling, C. J.; Biochem. Soc. Trans. 1991, 216; (g) Schultz, P. G.; Lerner, R. A.; Acc. Chem. Res. 1993, 26, 391; (h) Stewart, J. D.; Liotta, L. J.; Benkovic, S. J.; Acc. Chem. Res. 1993, 26, 396; (i) Stewart, J. D.; Benkovic, S. J.; Chem. Soc. Rev. 1993, 213; (j) Leumann, C.; Angew. Chem. Int. Ed. Engl. 1993, 32, 1291; (k) Zouali, M.; Hansen, D. E.; Trends Biotechnol. 1994, 12, 73; (1) Blackburn, G. M.; Wentworth, P.; Chem. Ind. 1994, 338; (m) Hilvert, D.; Curr. Opin. Struct. Biol. 1994, 4, 612; (n) Janda, K. D.; Pure Appl. Chem. 1994, 66, 703; (o) Scanlan, T. S.; Ann. Rev. Med. Chem. 1995, 30, 255; (p) Hsieh-Wilson, L. C., Xiang, X.-D.; Schultz, P. G.; Acc. Chem. Res. 1996, 29, 164.

15. Schultz, P. G.; Science 1988, 240, 426.

16. Hilvert, D.; Pure Appl. Chem. 1992, 64, 1103.

17. Hilvert, D.; Acc. Chem. Res. 1993, 26, 552.

18. (a) Stewart, J. D.; Krebs, J. F.; Siuzdak, G.; Berdis, A. J.; Smithrud, D. B.; Benkovic, S. J.; Proc. Natl. Acad. Sci. USA 1994, 91, 7404; (b) Siuzdak, G.; Krebs, J. F.; Benkovic, S. J.; Dyson, H. J.; J. Am. Chem. Soc. 1994, 116, 7937.

19. Jacobsen, S. R.; Schultz, P. G.; Curr. Opin. Struct. Biol. 1995, 5,818 .

20. Miyashita, H.; Hara, T.; Tanimura, R.; Tanaka, F.; Kikuchi, M.; Fujii, I.; Proc. Natl. Acad. Sci. USA 1994, 91, 6045.

21. Seiler, F. R.; Gronski, P.; Kurrle, R.; Luben, G.; Hartbus, H. P.; Ax, W.; Bosslet, K.; Schwick, H. G.; Angew. Chem. Int. Ed. Engl. 1985, 24, 139.

22. Tawfik, D. S.; Green, B. S.; Chap, R.; Sela, M.; Eshhar, Z.; Proc. Natl. Acad. Sci. USA 1993, 90, 373.
23. MacBeath, G.; Hilvert, D.; J. Am. Chem. Soc. 1994, 116, 6101.

24. Tawfik, D. S.; Zemel, R. R.; Arad-Yellin, R.; Green, B. S.; Eshhar, Z.; Biochemistry 1990, 29, 9916.

25. Thorn, S. N.; Daniels, R. G.; Auditor, M.-T. M.; Hilvert, D.; Nature 1995, 373, 228.

26. Pollack, S. J.; Hsium, P.; Schultz, P. G.; J. Am. Chem. Soc. 1989, 111, 5961.

27. Matayoshi, E. D.; Wang, G. T.; Krafft, G. A.; Erickson, J. W.; Science 1990, 247, 954.

28. Cummings, R. T.; Krafft, G. A.; Tetrahedron Lett. 1988, 29,65 .

29. (a) Huse, W. D.; Sastry, L.; Iverson, S. A.; Kang, A. S.; Alting-Mees, M.; Burton, D. R.; Benkovic, S. J.; Lerner, R. A.; Science 1989, 246, 1275; (b) McCafferty, J.; Griffiths, A. D.; Winter, G.; Criswell, D. J.; Nature 1990, 348, 552; (c) Kang, A. S.; Barbas, C. F.; Janda, K. D.; Benkovic, S. J.; Lerner, R. A.; Proc. Natl. Acad. Sci. USA 1991, 88, 4363; (d) Marks J. D.; Hoogenboom, H. R.; Bonnert, T. P.; McCafferty, J.; Griffiths, A. D.; Winter, G.; J. Mol. Biol. 1991, 222, 581; (e) Barbas III, C. F.; Kang, A. S.; Lerner, R. A.; Benkovic, S. J.; Proc. Natl. Acad. Sci. USA 1991, 88, 7978; (f) Barbas III, C. F.; Bain, J. D.; Hoekstra, D. M.; Lerner, R. A.; Proc. Natl. Acad. Sci. USA 1992, 89, 4457; (g) Lerner, R. A.; Kang, A. S.; Bain, J. D.; Burton, D. R.; Barbas III, C. F.; Science 1992, 258, 1313; (h) Gram, H.; Marconi, L. A., Barbas III, C. F.; Collet, T. A.; Lerner, R. A.; Kang, A. S.; Proc. Natl. Acad. Sci. USA 1992, 89, 3576; (i) Collet, T. A.; Roben, P.; O'Kennedy, R.; Barbas III, C. F.; Burton, D. R.; Lerner, R. A.; Proc. Natl. Acad. Sci. USA 1992, 89, 10026; (j) Barbas III, C. F.; Rosenblum, J. S.; Lerner, R. A.; Proc. Natl. Acad. Sci. USA 1993, 90, 6385; (k) Barbas III, C. F.; Amberg, W.; Simoncsits, A.; Jones, T. M.; Lerner, R. A.; Gene 1993, 137, 57; (1) Griffiths, A. D.; Williams, S. C.; Hartley, O.; Tomlinson, I. M.; Waterhouse, P.; Crosby, W. L.; Kontermann, R. E.; Jones, P. T.; Low, N. M.; Allinson, T. J.; Prospero, T. D.; Hoogenboom, H. R.; Nissim, A.; Cox, J. P. L.; Harrison, J. L.; Zaccolo, M.; Gherardi, E.; Winter, G.; EMBO J. 1994, 13, 3245.

30. Burton, D. R.; Acc. Chem. Res. 1993, 26, 405.

31. Posner, B.; Smiley, J.; Lee, I.; Benkovic, S. J.; Trends Biochem. Sci. 1994, 19, 145.

32. Sastry, L.; Alting-Mees, M.; Huse, W. D.; Short, J. M.; Sorge, J. A.; Hay, B. N.; Janda, K. N.; Benkovic, S. J.; Lerner, R. A.; Proc. Natl. Acad. Sci. USA 1989, 86, 5728.

33. Winter, G.; Milstein, C.; Nature 1991, 349, 293.

34. Hoogenboom, H. R.; Griffiths, A. D.; Johnson, K. S.; Criswell, D. J.; Hudson, P.; Winter, G.; Nucl. Acids Res. 1991, 19, 4133.

35. (a) Smith,G. P.; Science 1985, 228, 1315; (b) Burton, D. R.; Barbas III, C. F.; Adv. Immunol. 1994, 57, 191.

36. Janda, K. D.; Lo, C.-H. L.; Li, T.; Barbas III, C. F.; Wirsching, P.; Lerner, R. A.; Proc. Natl. Acad. Sci. USA 1994, 91, 2532.

37. Jacobs, J.; Schultz, P. G.; J. Am. Chem. Soc. 1987, 109, 2174.

38. Seebach, D.; Angew. Chem. Int. Ed. Engl. 1990, 29, 1320.

39. Janda, K. D.; Benkovic, S. J.; Lerner, R. A.; Science 1989, $244,437$.

40. Tramontano, A.; Ammann, A.; Lerner, R. A.; J. Am. Chem. Soc. 1988, 110, 2282.

41. Carter, P.; Wells, J. A.; Nature 1988, 332, 564.

42. Padlan, E.; J. Mol. Biol. 1986, 190, 593.

43. Durfor, C.N.; Bolin, R. J.; Sugasawara, R. J.; Massey, R. J.; Jacobs, J. W.; Schultz, P. G.; J. Am. Chem. Soc. 1988, $110,8713$.

44. Janda, K. D.; Ashley, J. A.; Jones, T. M.; McLeod, D. A.; Schloeder, D. M.; Weinhouse, M. I.; J. Am. Chem. Soc. 1990, 112, 8886.

45. Okahata, Y.; Yamaguchi, M.; Tanaka, F.; Fujii, I.; Tetrahedron Lett. 1995, 51, 7673. 
46. Janda, K. D.; Schloeder, D.; Benkovic, S. J.; Lerner, R. A; Science 1988, 241, 1188.

47. Iverson, B. L.; Lerner, R. A.; Science 1989, 243, 1184.

48. Martin, M. T.; Angeles, T. S.; Sugasawara, R.; Aman, N. I.; Napper, A. D.; Darsley, M. J.; Sanchez, R. I.; Booth, P.; Titmas, R. C.; J. Am. Chem. Soc. 1994, 116, 6508.

49. Baldwin, E.; Schultz, P. G.; Science 1989, 245, 1104.

50. Stewart, J. D.; Roberts, V. A.; Thomas, N. R.; Getsoff, E. D.; Benkovic, S. J.; Biochemistry 1994, 33, 1994.

51. Roberts, V. A.; Stewart, J.; Benkovic, S. J.; Getzoff, E. D.; J. Mol. Biol. 1994, 235, 1098.

52. Guo, J.; Huang, W.; Scanlan, T. S.; J. Am. Chem. Soc. 1994, 116, 6062 .

53. (a) Zhou, G. W.; Guo, J.; Huang, W.; Fletterick, R. J.; Scanlan, T. S.; Science 1994, 265, 1059; (b) Guo, J.; Huang, W.; Zhou, G. W.; Fletterick, R. J.; Scalan, T. S.; Proc. Natl. Acad. Sci. USA 1995, 92, 1694.

54. Wade, H.; Scanlan, T. S.; J. Am. Chem. Soc. 1996, 118, 6510.

55. Charbonnier, J.-B.; Carpenter, E.; Gigant, B.; GolinelliPimpaneau, B.; Eshhar, Z.; Green, B. S.; Knossow, M.; Proc. Natl. Acad. Sci. USA 1995, 92, 11721.

56. Shokat, K. M.; Leumann, C. J.; Sugasawara, R.; Schultz, P. G.; Nature 1989, 338, 269.

57. Shokat, K. M.; Uno, T.; Schultz, P. G.; J. Am. Chem. Soc. 1994, 116, 2261.

58. Uno, T.; Schultz, P. G.; J. Am. Chem. Soc. 1992, 114, 6573.

59. Reymond, J.-L.; Janda, K. D.; Lerner, R. A.; J. Am. Chem. Soc. 1992, 114, 2257.

60. Reymond, J.-L.; Jahangiri, G. K.; Stoudt, C.; Lerner, R. A.; J. Am. Chem. Soc. 1993, 115, 3909.

61. Jahangiri, G. K.; Reymond, J.-L.; J. Am. Chem. Soc. 1994, 116, 11264.

62. Jackson, D. Y.; Schultz, P. G.; J. Am. Chem. Soc. 1991, $113,2319$.

63. Li, T.; Janda, K. D.; Ashley, J. A.; Lerner, R. A.; Science 1994, 264, 1289.

64. Li, T.; Hilton, S.; Janda, K. D.; J. Am. Chem. Soc. 1995, 117, 3308.

65. Li, T.; Janda, K. D.; Lerner, R. A.; Nature 1996, 379, 326.

66. Napper, A. D.; Benkovic, S. J.; Tramontano, A.; Lerner, R. A.; Science 1987, 237, 1041.

67. Jackson, D. Y.; Jacobs, J. W.; Sugasawara, R.; Reich, S. H.; Bartlett, P.; Schultz, P. G.; J. Am. Chem. Soc. 1988, $110,4841$.

68. Hilvert, D.; Hill, K. W.; Nared, K. D.; Auditor, M.-T. M.; J. Am. Chem. Soc. 1989, 111, 9261.

69. Braisted, A.; Schultz, P. G.; J. Am. Chem. Soc. 1990, 112, 7430 .

70. Wirsching, P.; Ashley, J. A.; Benkovic, S. J.; Janda, K. D.; Lerner, R. A.; Science 1991, 252, 680.

71. Janda, K. D.; Lerner, R. A.; Tramontano, A.; J. Am. Chem. Soc. 1988, 110, 4835.

72. Cochran, A. G.; Sugasawara, R.; Schultz, P. G.; J. Am. Chem. Soc. 1988, 110, 7888.

73. Na, J.; Houk, K. N.; Hilvert, D.; J. Am. Chem. Soc. 1996, $118,6462$.

74. Gray, J. V.; Golinelli-Pimpaneau, B.; Knowles, J. R.; Biochemistry 1990, 29, 376.

75. (a) Bowdish, K.; Tang, Y.; Hicks, J. B.; Hilvert, D.; J. Biol. Chem. 1991, 266, 11901; (b) Shin, J. A.; Hilvert, D.; Bioorg. Med. Chem. Lett. 1994, 4, 2945; (c) Campbell, A. P.; Tarasow, T. M.; Massefski, W.; Wright, P. E.; Hilvert, D.; Proc. Natl. Am. Sci. USA 1993, 90, 8663 .

76. Haynes, M. R.; Stura, E. A.; Hilvert, D.; Wilson, I. A.; Science 1994, 263, 646.

77. Jackson, D. Y.; Liang, M. N.; Bartlett, P. A.; Schultz, P. G.; Angew. Chem. Int. Ed. Engl. 1992, 31, 182.

78. Wiest, O.; Houk, K. N.; J. Am. Chem. Soc. 1995, 117, 11628.
79. (a) Wiest, O.; Houk, K. N.; J. Org. Chem. 1994, 59, 7582; (b) Davidson, M. M.; Gould, I. R.; Hillier, I.; J. Chem. Soc. Chem. Commun. 1995, 63.

80. Oikawa, H.; Katayama, K., Suzuki, Y.; Ichihara, A.; J. Chem. Soc. Chem. Commun. 1995, 1321.

81. Reymond, J.-L.; Reber, J.-L.; Lerner, R. A.; Angew. Chem. Int. Ed. Engl. 1994, 33, 475.

82. Sinha, S. C.; Keinan, E. J.; J. Am. Chem. Soc. 1995, 117, 3653.

83. Bahr, N.; Güller, R.; Reymond, J.-L.; Lerner, R. A.; J. Am. Chem. Soc. 1996, 118, 3550.

84. (a) Reymond, J.-L.; Chen, Y.; Tetrahedron Lett. 1995, 36, 2575; (b) Reymond, J.-L.; Chen, Y.; J. Org. Chem. 1995, 60, 6970 .

85. Koch, T.; Reymond, J.-L.; Lerner, R. A.; J. Am. Chem. Soc. 1995, 117, 9383.

86. (a) Pollack, S. J.; Nakayama, G. R.; Schultz, P. G.; Science 1988, 242, 1038; (b) Pollack, S. J.; Schultz, P. G.; J. Am. Chem. Soc. 1989, 111, 1929.

87. Janjic, N.; Tramontano, A.; J. Am. Chem. Soc. 1989, 111, 9109.

88. Hsieh, L. C.; Stephans, J. C.; Schultz, P. G.; J. Am. Chem. Soc. 1994, 116, 2167.

89. Koch, A.; Reymond, J.-L.; Lerner, R. A.; J. Am. Chem. Soc. 1994, 116, 803.

90. Hsieh, L. C.; Yonkovich, S.; Kochersperger, L.; Schultz, P. G.; Science 1993, 260, 337.

91. (a) Kitazume, T.; Lin, J. T.; Yamamoto, T.; Yamazaki, T.; J. Am. Chem. Soc. 1991, 113, 8573; (b) Iwabuchi, Y.; Miyashita, H.; Tanimura, R.; Kinoshita, K.; Kikuchi, M.; Fujii, I.; J. Am. Chem. Soc. 1994, 116, 771.

92. Shabat, D.; Itzhaky, H.; Reymond, J.-L.; Keinan, E.; Nature 1995, 374, 143.

93. Gouverneur, V. E.; Houk, K. N.; de Pacual-Teresa, B.; Beno, B.; Janda, K. D.; Lerner, R. A.; Science 1993, 262, 204.

94. Murata, M.; Naoki, H.; Matsunaga, S.; Satake, M.; Yasumoto, T.; J. Am. Chem. Soc. 1994, 116, 7098.

95. Janda, K. D.; Shevlin, C. G.; Lerner, R. A.; J. Am. Chem. Soc. 1995, 117, 2659.

96. Janda, K. D., Shevlin, C. G.; Lerner, R. A.; Science 1993, 259,490

97. Cravatt, B. F.; Ashley, J. A.; Janda, K. D.; Boger, D. L.; Lerner, R. A.; J. Am. Chem. Soc. 1994, 116, 6013.

98. (a) Jacobsen, J. R.; Prudent, J. R.; Kochersperger, L.; Yonkovich, S.; Schultz, P. G.; Science 1992, 256, 365; (b) Jacobsen, J. R.; Schultz, P. G.; Proc. Natl. Acad. Sci. USA 1994, 91, 5888.

99. Uno, T.; Gong, B.; Schultz, P. G.; J. Am. Chem. Soc. 1994, 116, 1145.

100. Braisted, A. C.; Schultz, P. G.; J. Am. Chem. Soc. 1994, 116, 2211.

101. Yli-Kauhaluoma, J. T.; Ashley, J. S.; Lo, C.-H.; Tucker, L.; Wolfe, M. M.; Janda, K. D.; J. Am. Chem. Soc. 1995, 117, 7041.

102. Fujii, I.; Tanaka, F.; Miyashita, H.; Tanimura, R.; Kinoshita, K.; J. Am. Chem. Soc. 1995, 117, 6199.

103. (a) Lerner, R. A.; Benkovic, S. J.; BioEssays 1988, 9, 107; (b) Green, B. S.; Tawfik, D. S.; Trends Biotechnol. 1989, 7, 304; (c) Bagshawe, K. D.; Br. J. Cancer 1989, 60, 275; (d) Lerner, R. A.; Benkovic, S. J.; ChemtractsOrg. Chem. 1990, 3, 1; (e) Schultz, P. G.; Lerner, R. A.; Benkovic, S. J.; Chem. Eng. News 1990, 68, 26.

104. (a) Landry, D. W.; Zhao, K.; Yang, G. X.-Q.; Glickman, M.; Georgiadis, T. M.; Science 1993, 259, 1899; (b) Miyashita, H.; Karaki, Y.; Kikuchi, M.; Fujii, I.; Proc. Natl. Acad. Sci. USA 1993, 90, 5337; (c) Smiley, J. A.; Benkovic, S. J.; J. Am. Chem. Soc. 1995, 117, 3877; (d) Yang, G.; Chun, J.; Arakawa-Uramoto, H.; Wang, X.; Gawinowicz, M. A.; Zhao, K.; Landry, D. W.; J. Am. Chem. Soc. 1996, 118, 5881; (e) Wentworth, P.; Datta, A.; Blakey, D.; Boyle, T.; Partridge, L. J.; Blackburn, G. M.; Proc. Natl. Acad. Sci. USA 1996, 93, 799. 